\title{
The Role of Mental Accounting in Self-employed Business Owners' Tax Behavior (Case Study: Self-employed Taxpayers of Fars Province)
}

\author{
Fahime Ebrahimi * \\ Assistant Professor, Jahrom University (Corresponding author) \\ febrahimi@jahromu.ac.ir \\ Zahra Najafi \\ Chief Tax Auditor, State Tax Administration of Fars Province \\ najafi_zahra00@yahoo.com
}

\begin{abstract}
:
The business income tax is major source of tax revenues due to its importance and size. The purpose of this research is to investigate the role of mental accounting in shaping tax behavior of self-employed taxpayers. This is a survey research and the statistical population is comprised of individual taxpayers in Fars province in 2019. Hypothesis testing using $\mathrm{R}$ based on a sample of 184 small business owners revealed that self-employed taxpayers vary in how they use mental accounting and do tax calculations. They can be divided into segregators and integrators. Furthermore, the results revealed a significant difference between mental accounting of income tax and value-added tax (VAT). Taxpayers are more likely to segregate their mental accounts for VAT than they do for income tax. In addition, there is a positive relationship between tax knowledge and using mental accounting and a positive relationship between mental accounting and tax compliance. Therefore, it is important for the government to promote small business owners' knowledge that can influence their mental accounting and, in turn, their tax compliance.
\end{abstract}

Keyword: Mental Accounting, Self-employed Taxpayers, Income Tax, VAT, Tax Compliance.

\section{Copyrights}

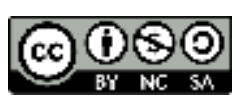

This license only allowing others to download your works and share them with others as long as they credit you, but they can't change them in any way or use them commercial. 


\section{مقاله بُؤوهى}

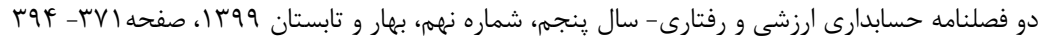

\section{نقش حسابدارى ذهنى در رفتار مالياتى خويش فرمايان \\ (مورد مطالعه: مؤديان حقيقى استان فارس)

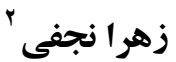

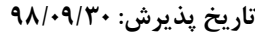 \\ فهيمه ابر اهيمى :

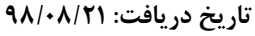

جكيده

بخش مشاغل يكى از بخشهاى تأمين كننده ماليات است كه به دليل اهميت و گستردكى

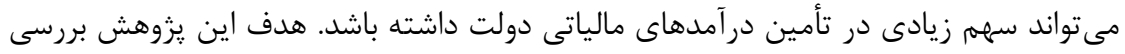
نقش حسابدارى ذهنى در رفتار مالياتى خويشفرمايان است. اين يزوهش از نوع يزوهش برهاى

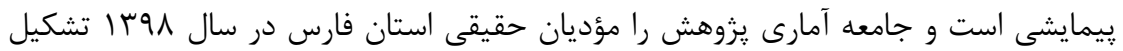

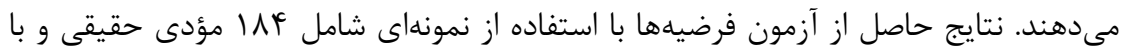
بهره ميرى از نرمافزار R بيانگر اين است كه خويشفرمايان در استفاده از حسابدارى ذهنى و

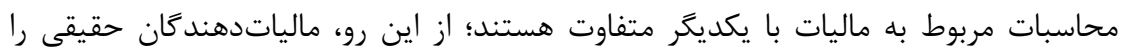

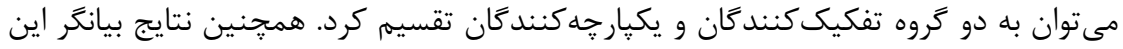

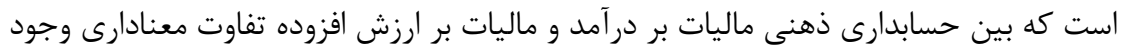

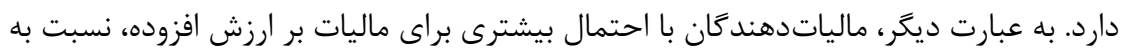
ماليات بر درآمد، حساب ذهنى جداگَانه در نظر مى گيرند. افزون بر اين، رابطه مثبتى بين دانش مالياتى و استفاده از حسابدارى ذهنى و همجنين بين حسابدارى ذهنى و تمكين مالياتى وجود دارد. با توجه به نتايج بدست آمده، در راستاى تأمين درآمدهاى مالياتى دولت، توجه به عواملى ودئى مانند ارتقاى دانش مالياتى مؤديان حقيقى كه مىتواند بر حسابدارى ذهنى و تفكيك ذهنى

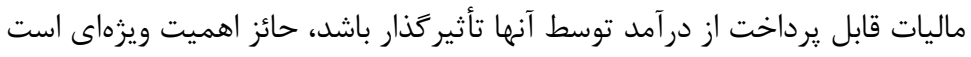
وازًان كليدى: حسابدارى ذهنى، خويشفرمايان، ماليات بر درآمد، ماليات بر ارزش افزوده،

تمكين مالياتى.

febrahimi@jahromu.ac.ir)'استاديار حسابدارى دانشگاه جهرم، (نويسنده مسئول'

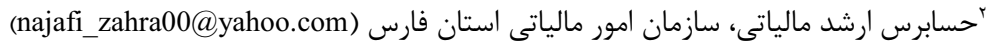


امروزه ماليات به عنوان يكى از مهممترين منابع درآمدى دولتها، در اقتصاد هر كشورى نقش

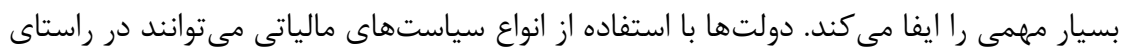

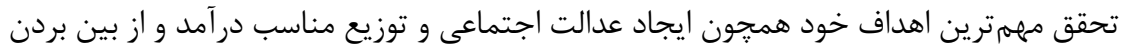
شكاف طبقاتى بين اقشار مختلف جامعه، تثبيت قيمتها، كاهش بيكارى، رونق اقتصادى و نيز

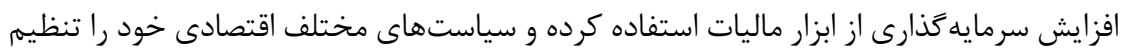

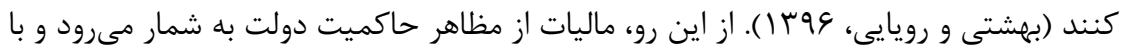

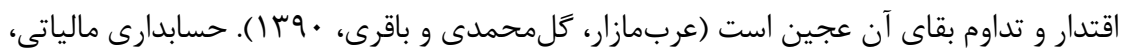
به عنوان شاخهاى از حسابدارى، بيانگر مسئوليت بزرگ حرفه حسابدارى در تأمين اهداف نظام نام مالياتى كشور است. بخش مشاغل يكى از بخش هاى تأمين كننده ماليات است كه به دليل اهميت و گسترد مىتواند سهم زيادى در تأمين درآمدهاى مالياتى دولت داشته باشد. عمدهترين ويزگى مؤديان مالياتى اين بخش كه با عنوان خويشفرمايان يا صاحبان مشاغل شناخته مى شىوند، استفاده از داز

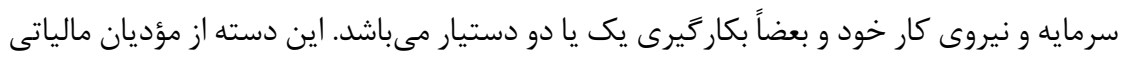

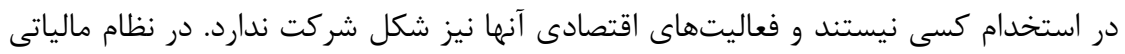

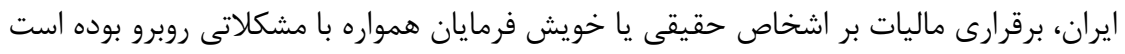

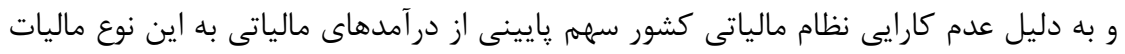

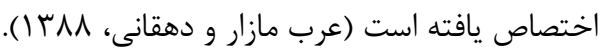

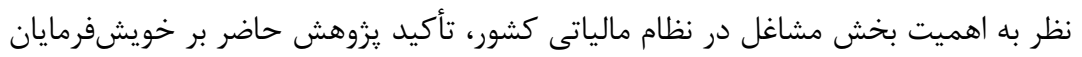
است. اين دسته از مالياتدهندگان هم از ديدگاه تحقيقاتى و هم از ديدگاه نظام مالياتى حائز

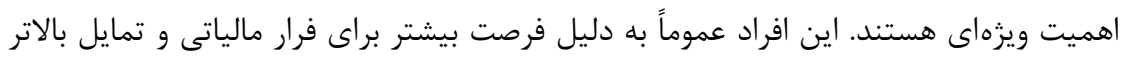
براى گذيرش ريسك مالى ذاتى فرار مالياتى، نسبت به حقوق بكيران از تمكين مالياتى كمترى برخوردار مىباشند. افزون بر اين، اين نوع مالياتدهندگان بايد جند نوع ماليات يرداخت كرده و

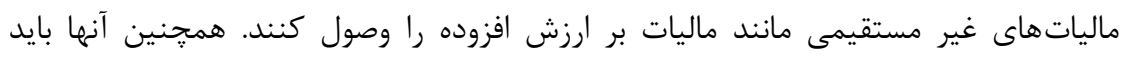

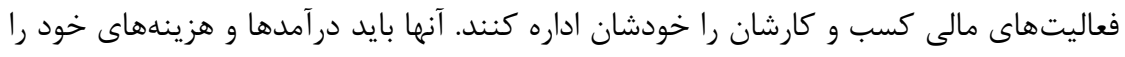

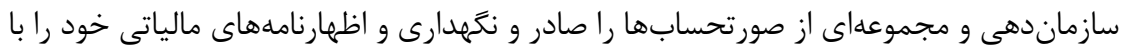
كمك يا بدون كمك يك كارشناس مالياتى، كه عموماً يك حسابدار حرفهاى است، براى ايفاى

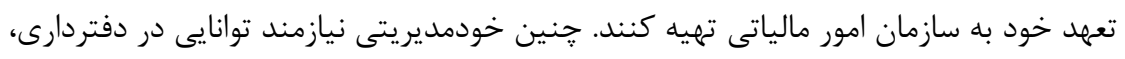

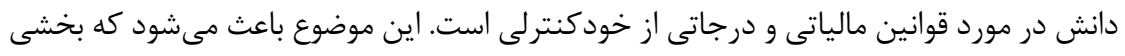

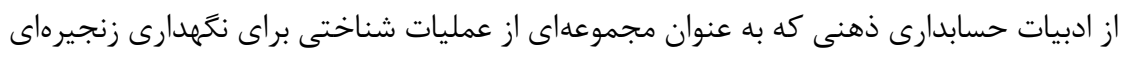


از فعاليتهاى مالى يك شخص و به عنوان يك استراتزى براى مديريت يول و غلبه بر مشكلات

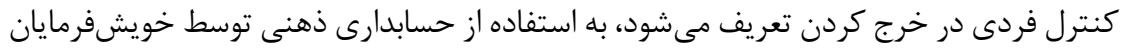

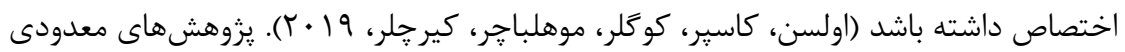

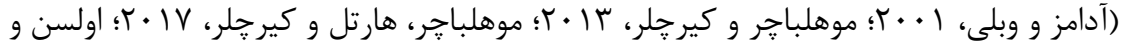

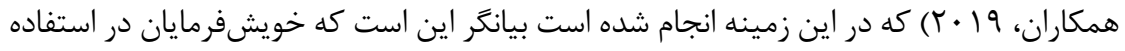

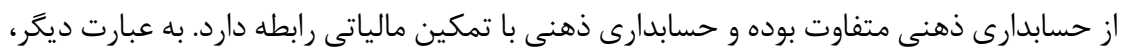

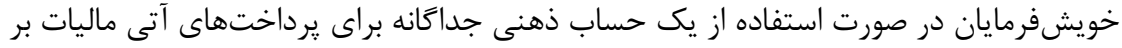

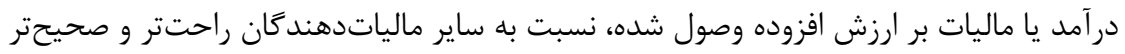

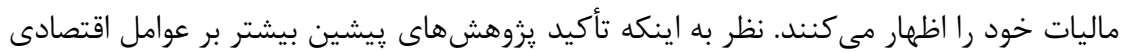

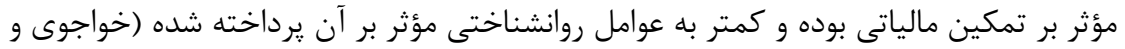

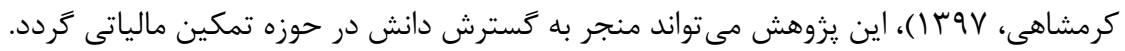

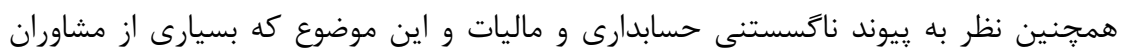

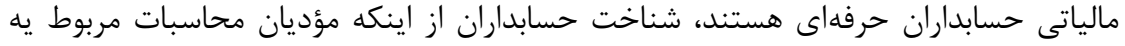

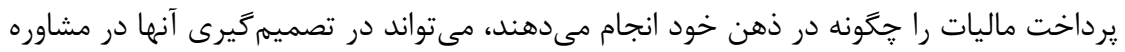

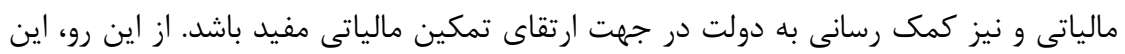
يزوهش منجر به كسترش دانش در حوزه حسابدارى مالياتى نيز مى كردد.

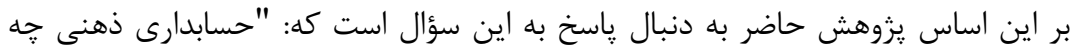

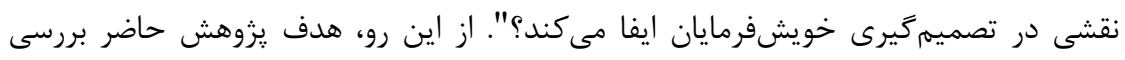

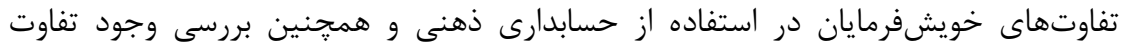

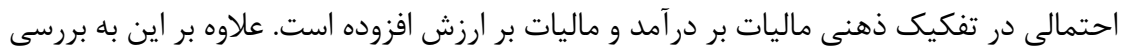

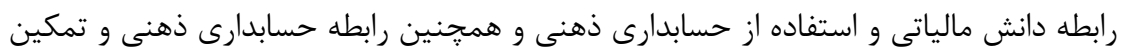
مالياتى يرداخته مىشود.

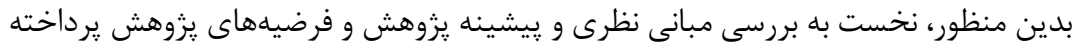

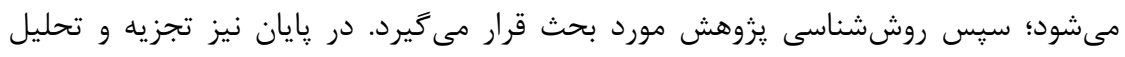

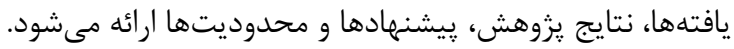

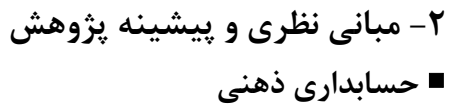

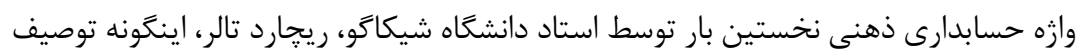

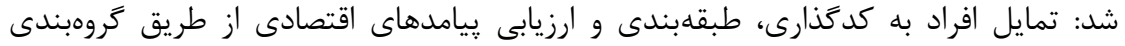


امتيازات آنها در مجموعهاى از حسابهاى ذهنى (تالر، له19 1). در سال 1999 اوى تعريف جديدى

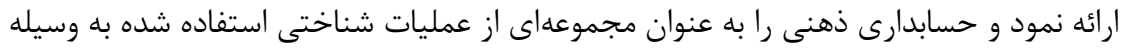

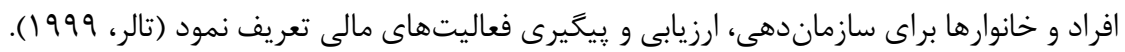

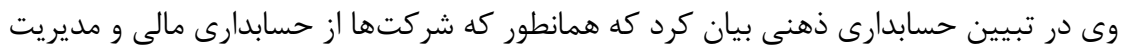

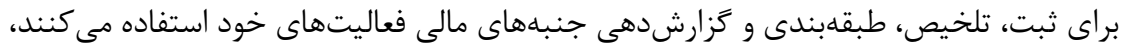

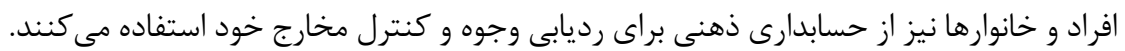

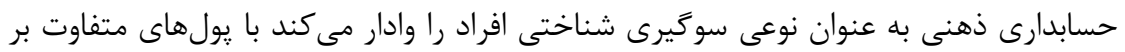

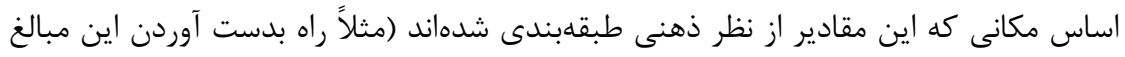

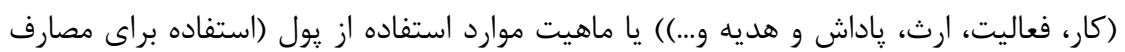
تفريحى، استفاده براى رفع مايحتاج و...) رفتار غيرعقلايى از خود نشان دهند (يمبين، (1TNN/19GK اكر جه نَحهدارى حسابهاى ذهنى در بعضى مواقع منجر به رفتارهاى غيرمنطقى مى

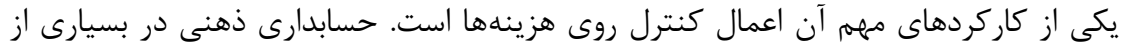

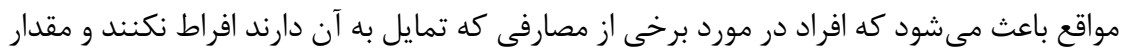

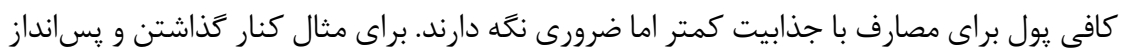

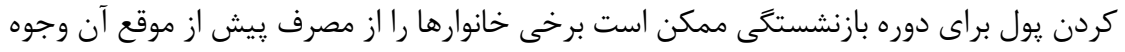

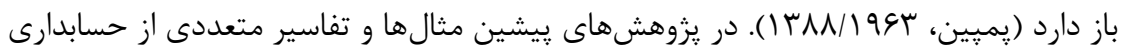

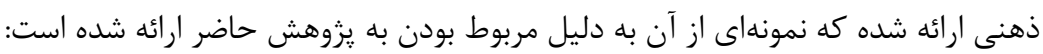

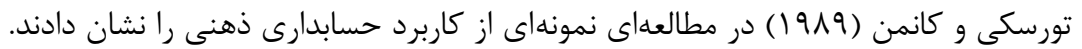

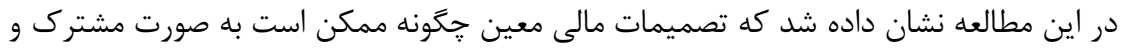

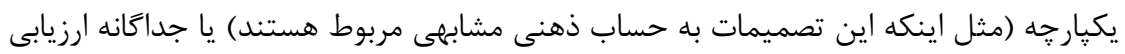

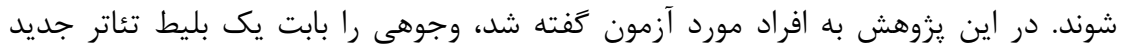

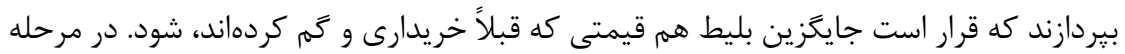

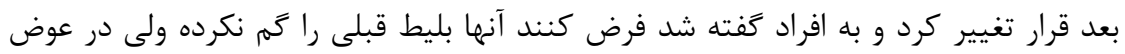

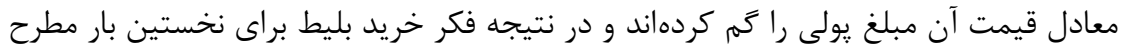

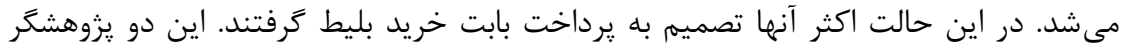

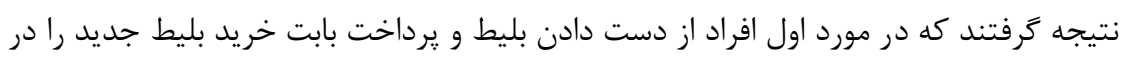

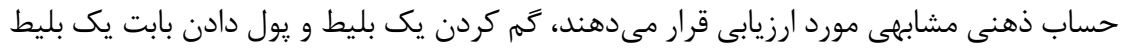

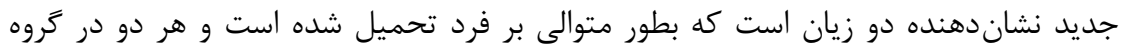

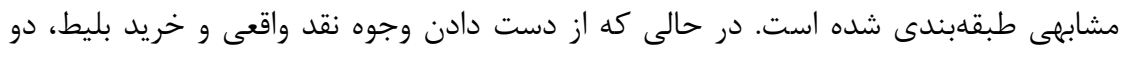


حساب هستند كه به طور مجزا مورد ارزيابى قرار گرفتهاند. بنابراين وقتى همان زيان از دو حساب

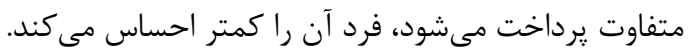

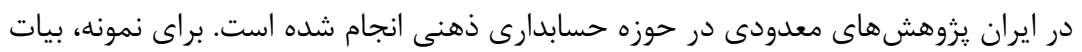

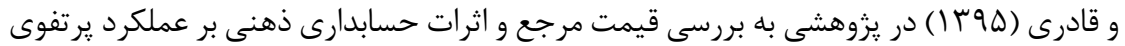

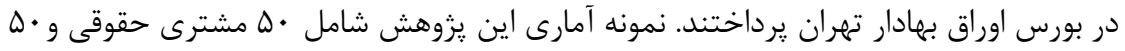

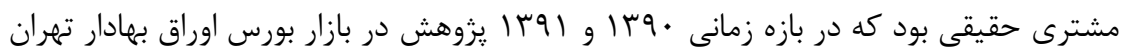

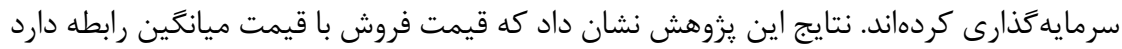

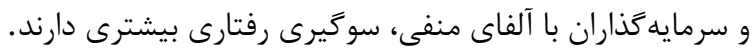

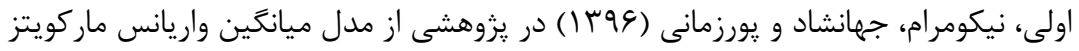

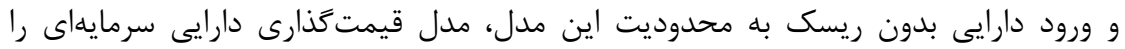

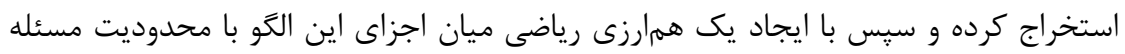

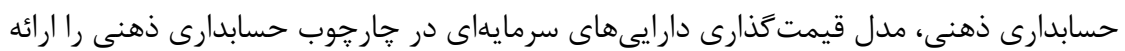

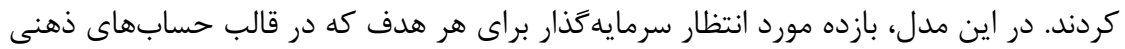

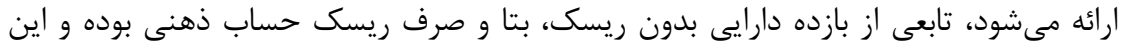

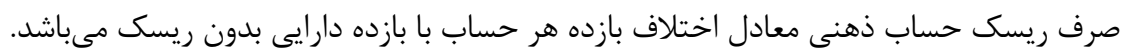

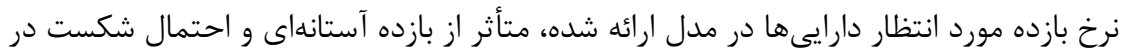

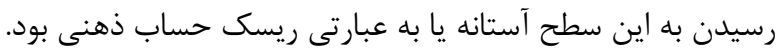

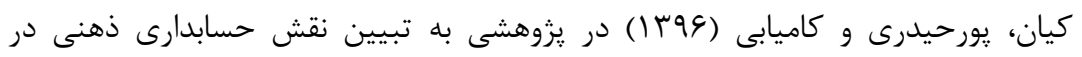

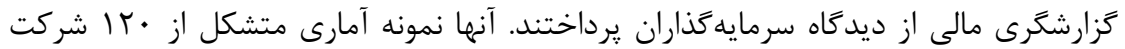

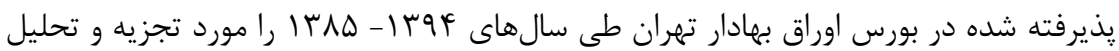

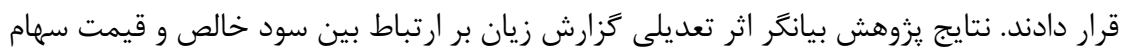

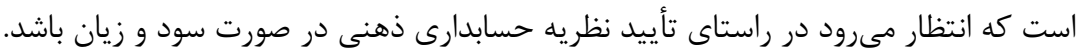

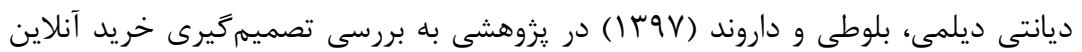

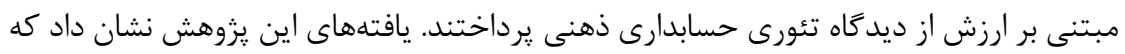

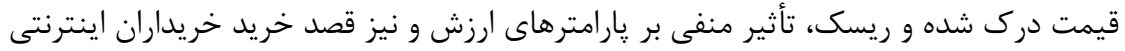

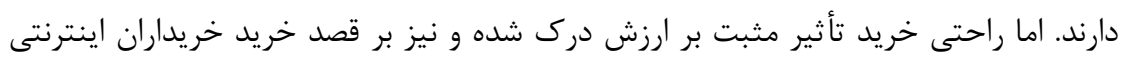

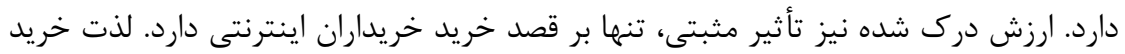

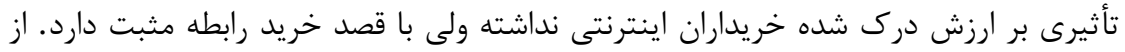

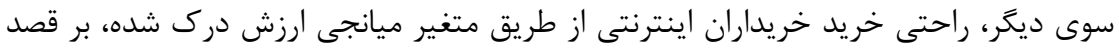


خريد تأثير مثبت دارد. ولى قيمت درك شده و ريسك درك شده از خريد، از طريق متغير ميانجى

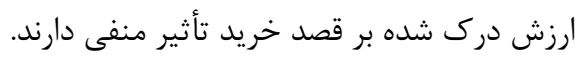

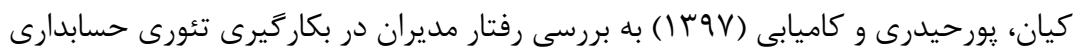

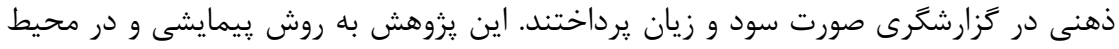

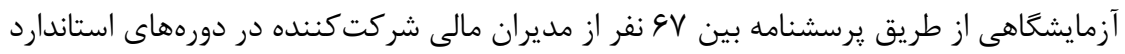

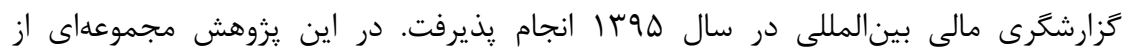

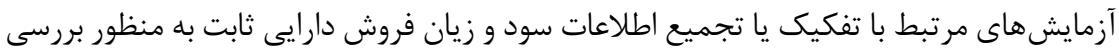

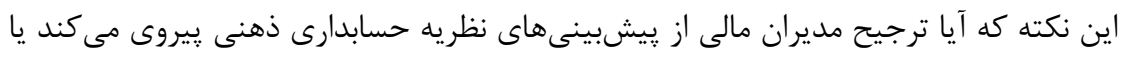

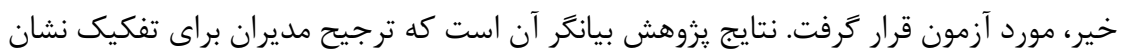
دهنده حسابدارى ذهنى مى باشد.

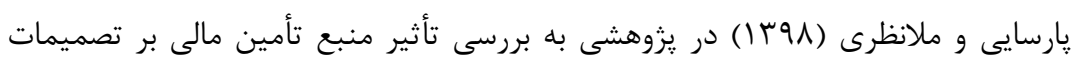

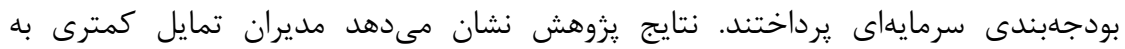

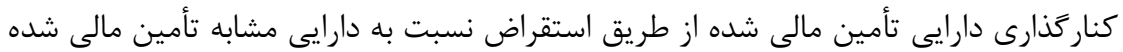

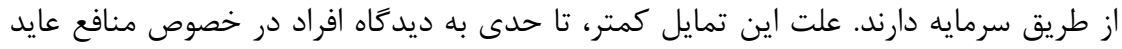

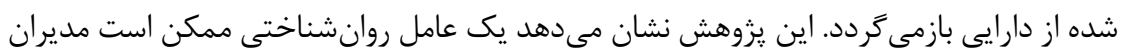

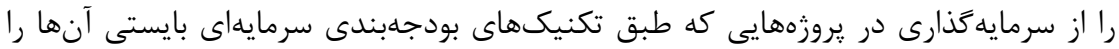

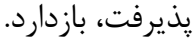

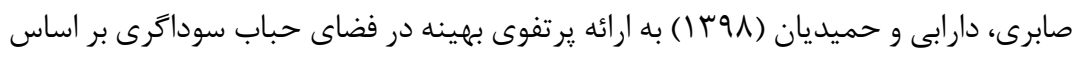

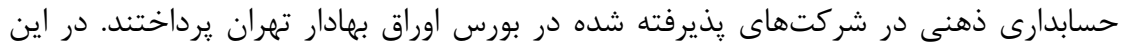

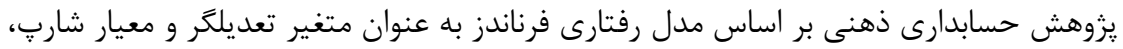

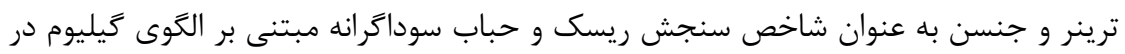

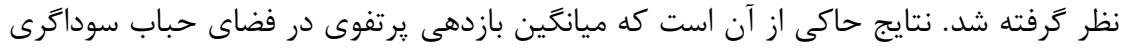

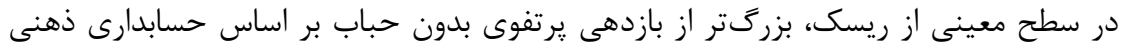

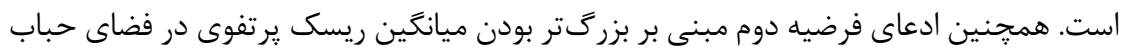

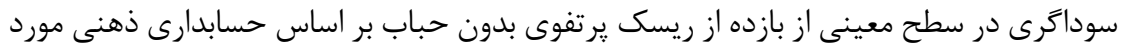

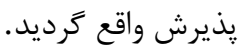

\section{ت تسابدارى ذهنى و ماليات}

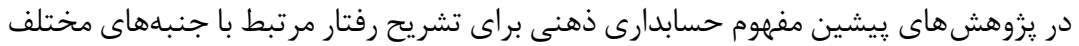

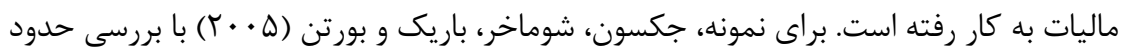


هفتاد اظهارنامه مالياتى بيان نمودند كه مالياتدهندكانى كه استرداد مالياتى دريافت مى كنند

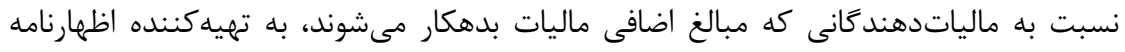

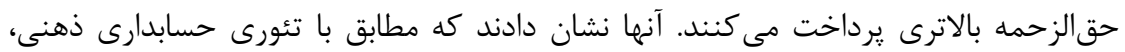

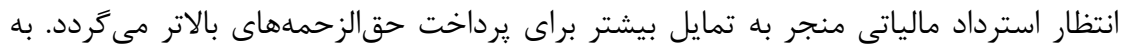

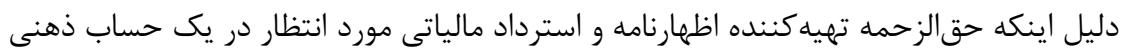
واحد طبقابندى مى شود، مبلغ حق الزحمه به صورت ذهنى از استرداد مالياتى كسر مى گرددد. از

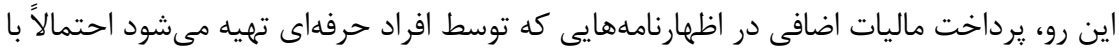

$$
\text { قصد صورت مى كيرد. }
$$

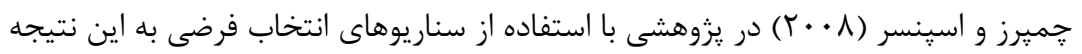

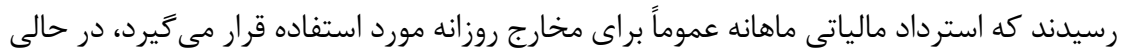

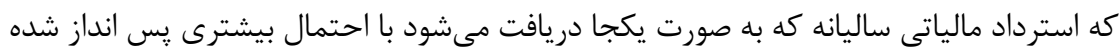
يا براى يرداخت بدهى مورد استفاده قرار مى كيرد. يزوهشهاى اندكى در مورد نقش حسابدارى ذهنى در تمكين مالياتى انجام شده است. براى دردي

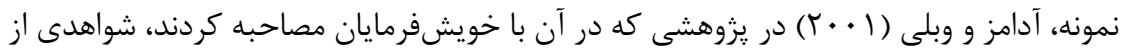

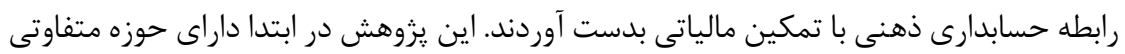

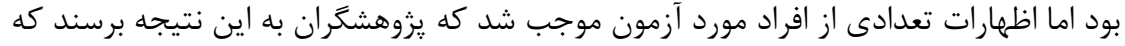

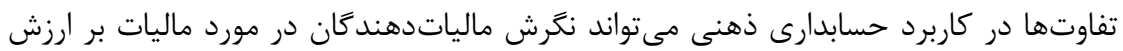

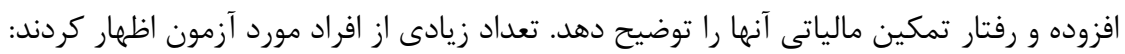

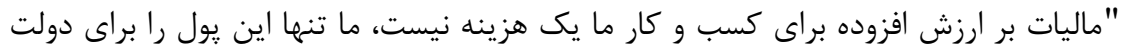

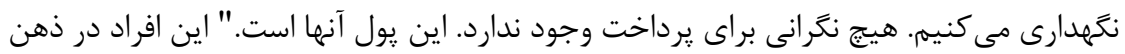

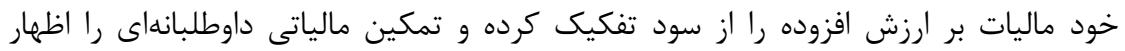

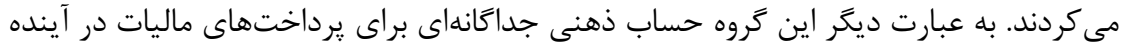

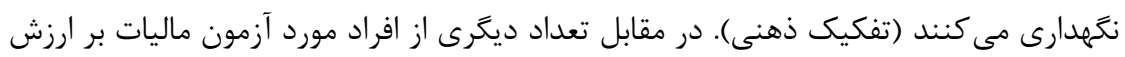

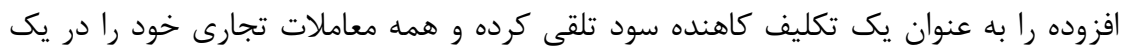

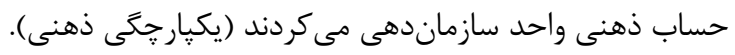

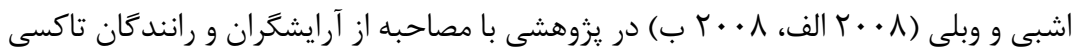

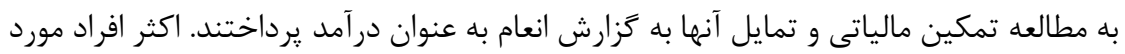

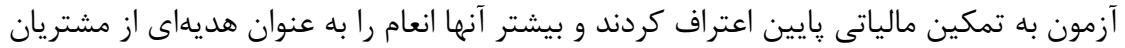

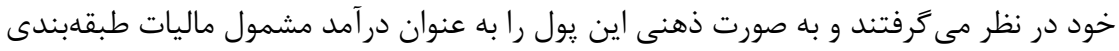

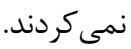




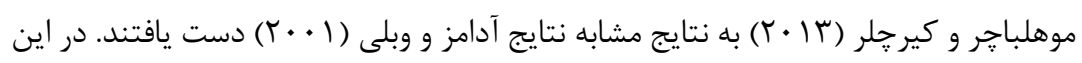

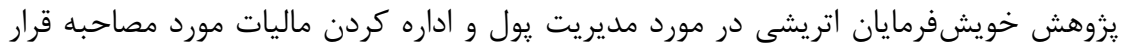

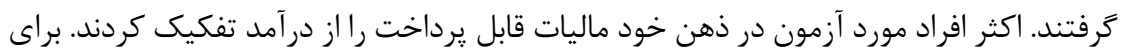

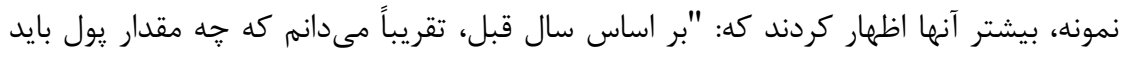

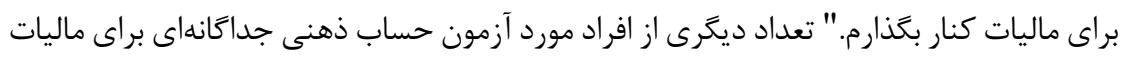

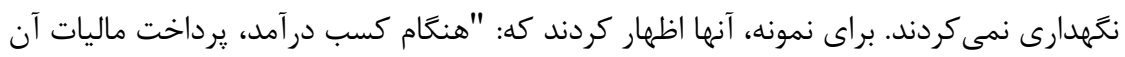

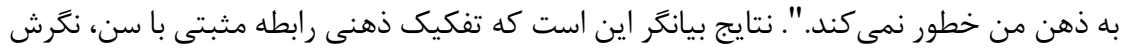

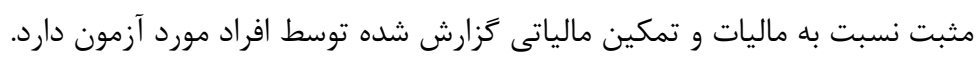

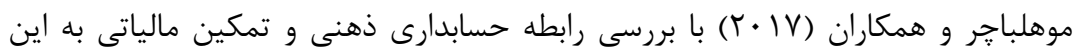

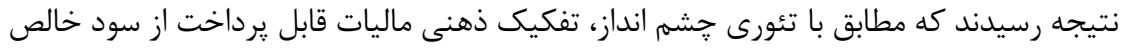

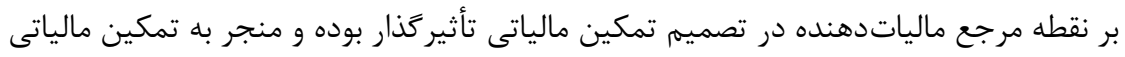

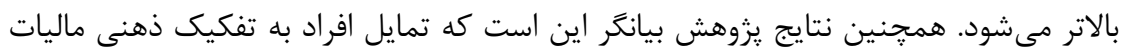

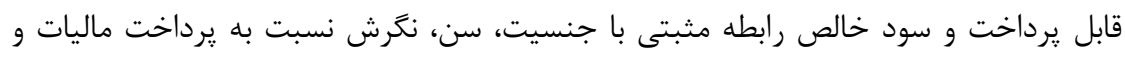
تجربه دارد.

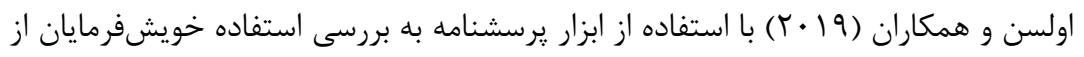

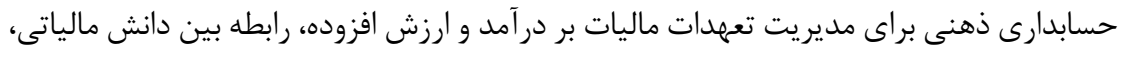

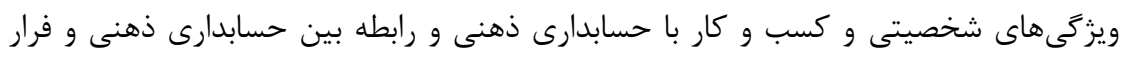

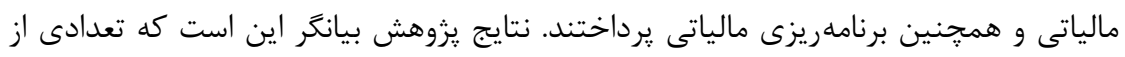

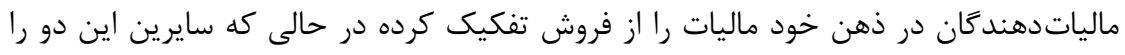

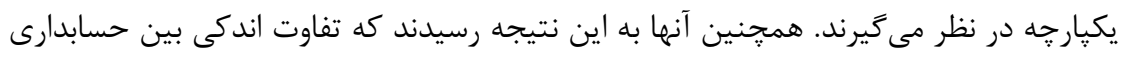

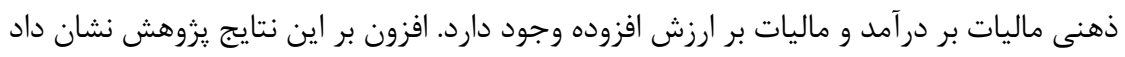

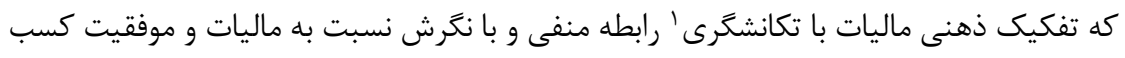

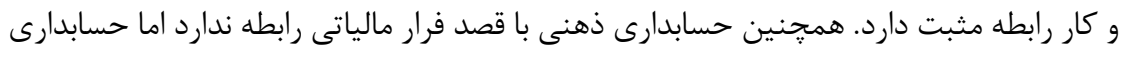
ذهنى رابطه مثبتى با برنامهريزى مالياتى دارد.

\section{r- فرضيههاى يزوهش}

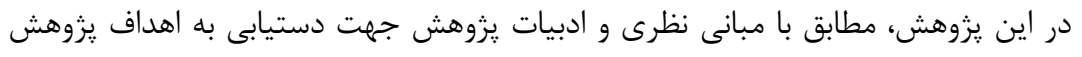
فرضيههايى به شرح زير تدوين شد:

1- Impulsivity 


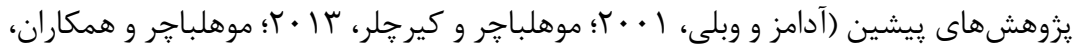

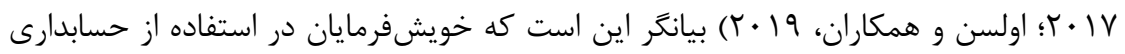

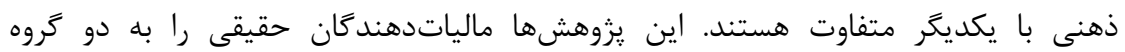
تفكيك كنند

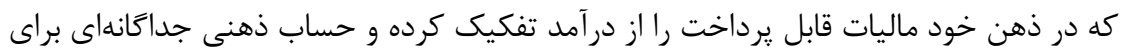

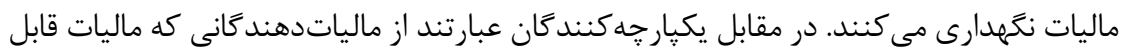

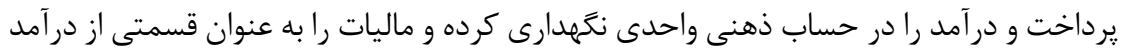

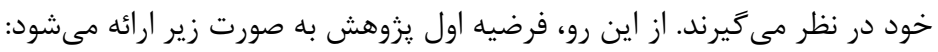

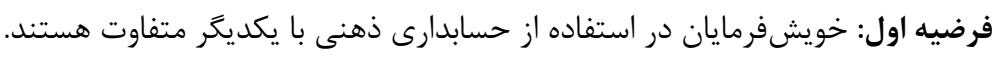

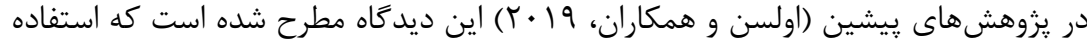

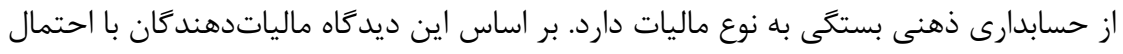

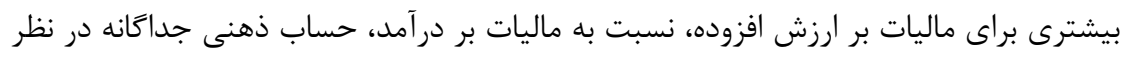

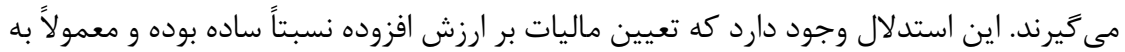

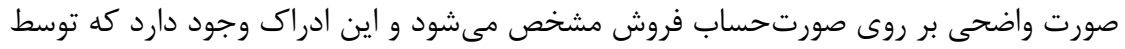

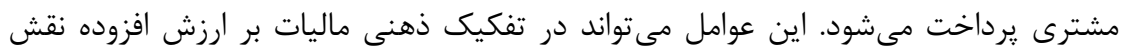

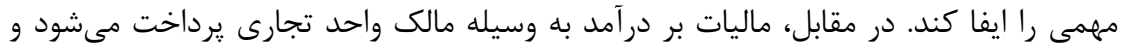

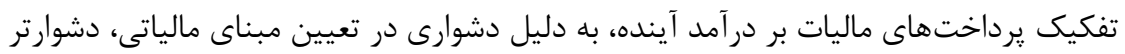

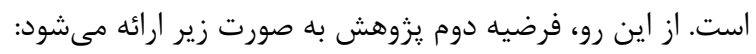

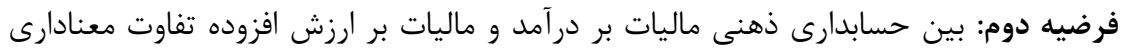

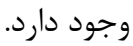
تعيين ميزان صحيح ماليات توسط خويشفرمايان نيازمند دانش كستردهاى از قوانين مالياتى

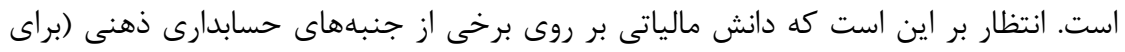

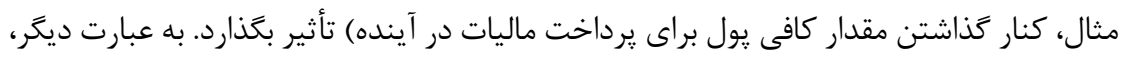

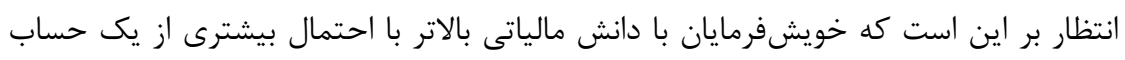

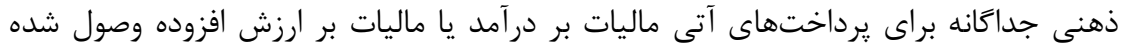

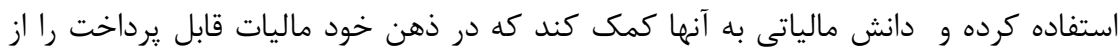

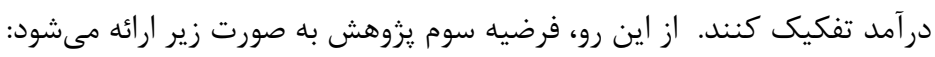

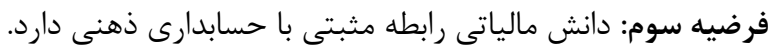




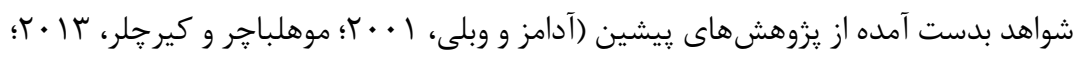

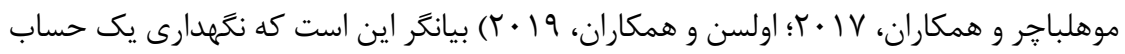
جداگانه براى ماليات قابل يرداخت موجب افزايش تمكين مالياتى مى

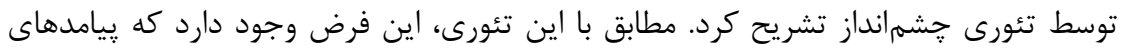

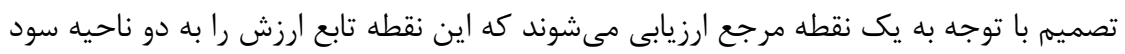

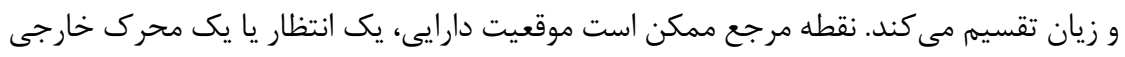

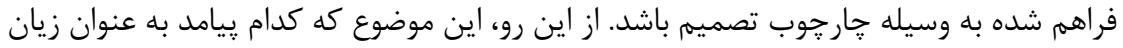

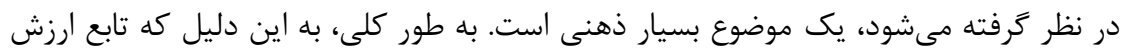

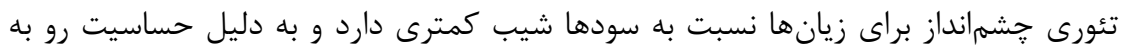

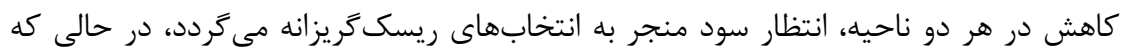

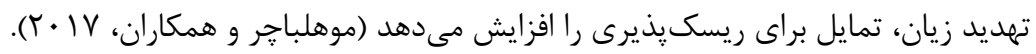
حسابدارى ذهنى مىتواند نقش كليدى در تعيين اينكه كدام نقطه در تصميمات تمكين

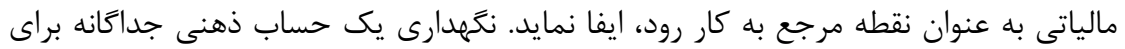

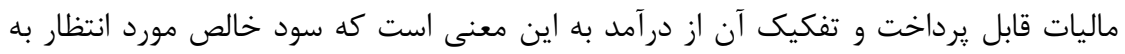

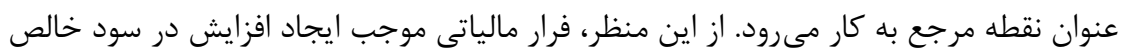

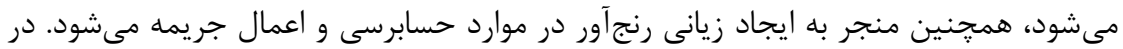

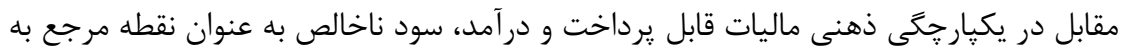

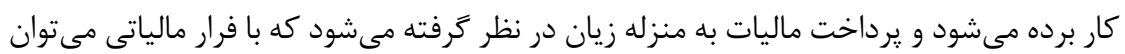

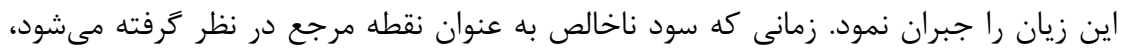

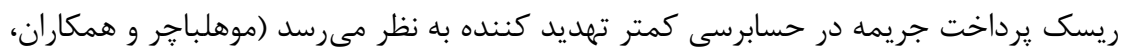

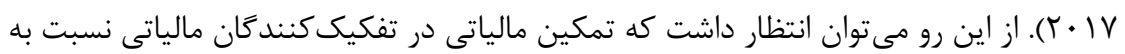

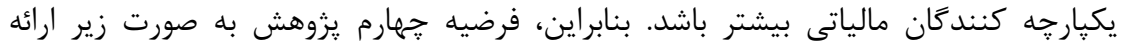
فرضيه جهارم: حسابدارى ذهنى رابطه مثبتى با تمكين مالياتى دارد.

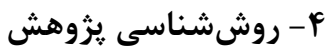

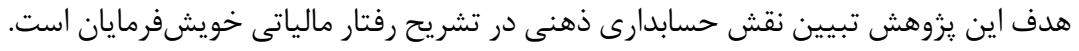

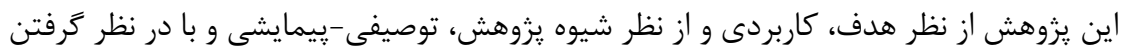

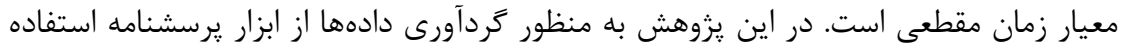

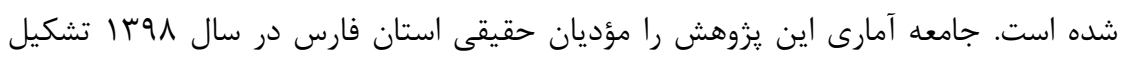




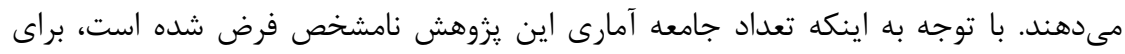

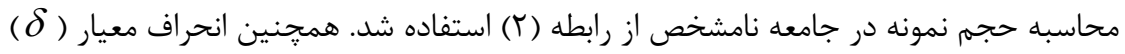

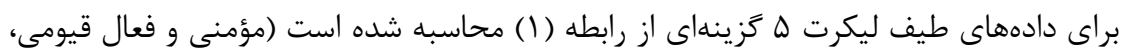

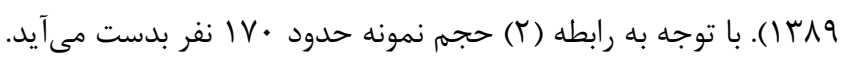

$$
\begin{gathered}
\delta=\frac{\max \left(x_{i}\right)-\min \left(x_{i}\right)}{q}=\frac{\Delta-1}{\varphi}=\cdot / 49 \vee \\
n=\frac{z^{r} \alpha / \delta^{r}}{\varepsilon^{r}}=\frac{(1 / 94)^{r}(. / 49 \vee)^{r}}{(. / 1)^{r}}=1 \mathrm{~V} .
\end{gathered}
$$

در اين يزوهش از نمونه

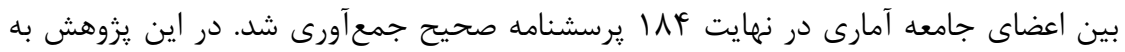

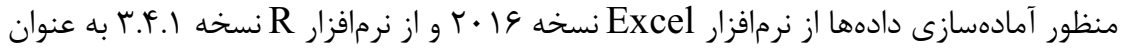
ابزار تجزيه و تحليل استفاده شد. يرسشنامه مورد استفاده در اين يزوهش حاوى دو بخش است؛ بخش اول شاده شامل ه هؤال است كه اين سؤالها اطلاعات جامعهشناختى شامل جنسيت، سطح تحصيلات، سن، تجربه كارى و شغل קٍاسخدهند ذهنى و تمكين مالياتى اختصاص دارد. به منظور سنجش اين سازهها از يرسشنامه ارائه شده دهان

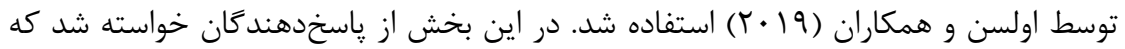
ميزان موافقت خود را با هر ززاره بر اساس طيف ليكرت ه گزينهاى (از إن بسيار كم تا هـ= بسيار زياد) بيان نمايند.

يرسشنامه دانش مالياتى، كه حاوى ^ يرسش است، به ارزيابى دانش مالياتى ياسخدهندكان

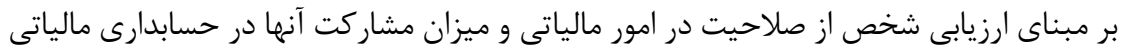

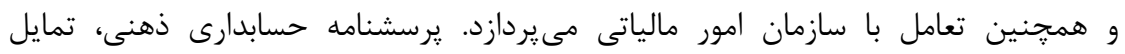
ֶاسخدهندگان جهت به كارگيرى حسابدارى ذهنى در ماليات عمومى، ماليات بر درآمد و ماليات

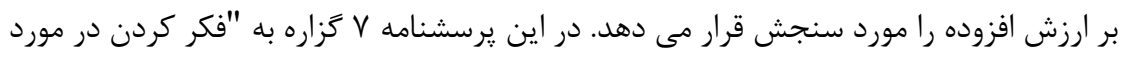

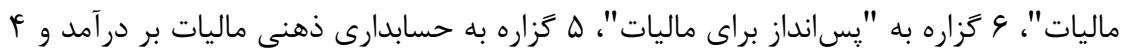
گززاره به حسابدارى ذهنى ماليات بر ارزش افزوده اختصاص دارد. بخش جهارم نيز با تمايز قائل

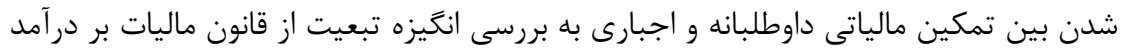

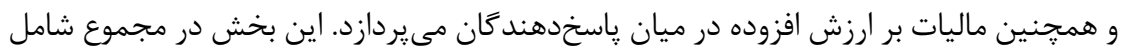
^ گزاره است. 
در اين يزوهش به منظور حصول اطمينان از روايى از روش "روايى صورى" استفاده به عمل

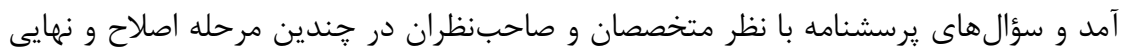

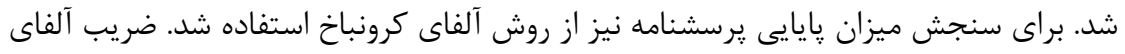

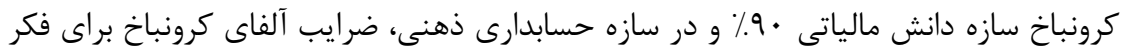

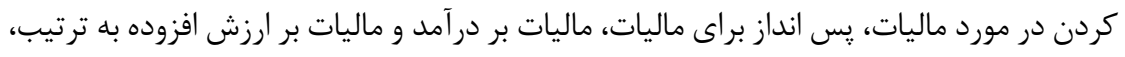

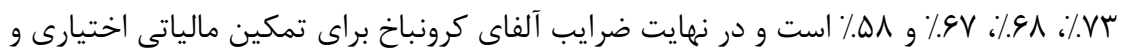

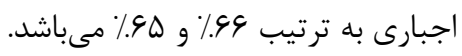

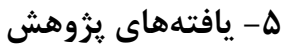

جدول ا، آمارههاى توصيفى متغيرهاى مورد مطالعه شامل ميانكين، انحر اف استاندارد، جولنى

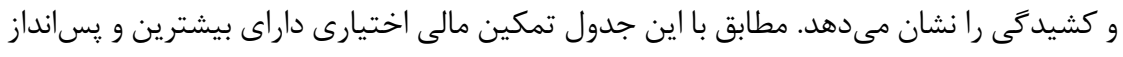

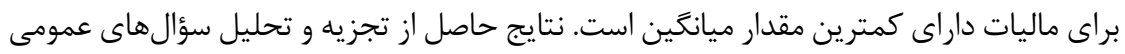

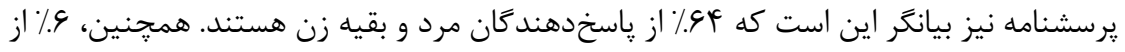
"ياسخدهند

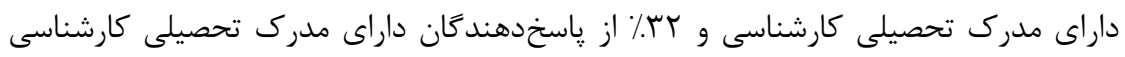

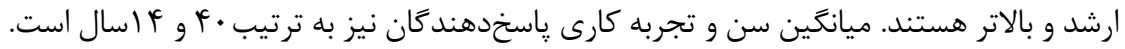

\begin{tabular}{|c|c|c|c|c|}
\hline \multicolumn{5}{|c|}{ جدول 1: امار توصيقى سازههاى يزّوهش } \\
\hline كشيدكى & جولكى & انحر اف معيار & ميانغين & سازه حسابدارى ذهنى \\
\hline$-\cdot / 19$ & . 194 & $\cdot / 179$ & $r / 4)$ & فكر كردن در مورد ماليات \\
\hline .149 & $\cdot / \& \mathrm{~V}$ & $\cdot|\mathrm{A}|$ & T/AY & يس إنداز براى ماليات \\
\hline$-\cdot \cdot 1 \cdot V$ & $-\cdot / 4 r$ & $\cdot|\wedge|$ & $\mu / \cdot r$ & ماليات بر درآمد \\
\hline$-\cdot \mid \Delta \Lambda$ & $-\cdot 119$ & $\cdot \mid 149$ & $r / \cdot 1$ & ماليات بر ارزش افزوده \\
\hline$-\cdot / r \cdot$ & $-\cdot / 1 \Delta$ &.$/ 9 V$ & $r / T$ & دانش مالياتى \\
\hline$\cdot \mid \Delta r$ & $-\cdot / Q F$ & $\cdot \mid \mathrm{AV}$ & $r / 09$ & تمكين مالياتى اختيارى \\
\hline$\cdot . / Q T$ & $-\cdot / \Delta$ & $\cdot / \mathrm{A} \Lambda$ & $r / \Delta V$ & تمكين مالياتى اجبارى \\
\hline
\end{tabular}

نتايج حاصل از آزمون فرضيهها

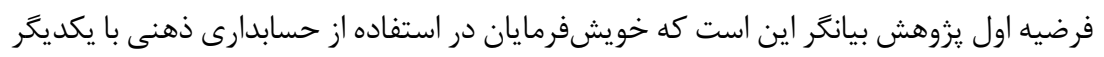

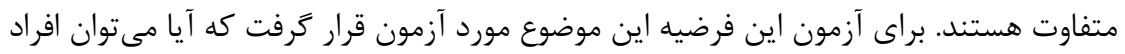

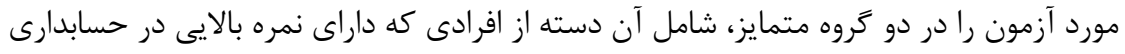

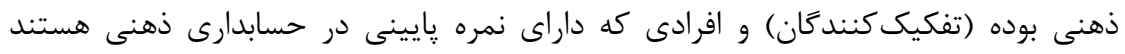




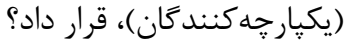

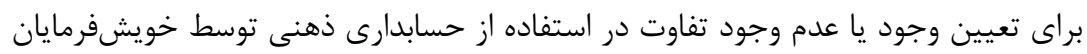

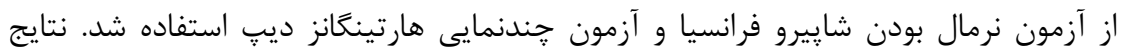

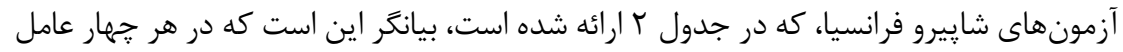

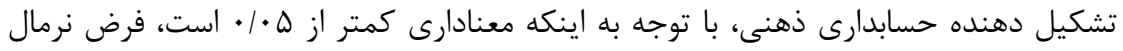

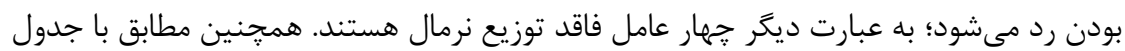

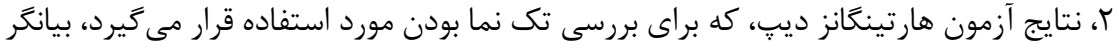

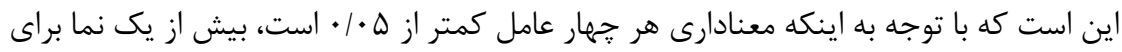
جهار عامل حسابدارى ذهنى وجود دارد. جدول ז: نتايج حاصل از آزمون شإيرو فرانسيا و هارتيخانز ديٍ براى عوامدامل حسابدارى ذهنى

\begin{tabular}{|c|c|c|c|c|}
\hline \multicolumn{2}{|c|}{ آزمون هار تينكَانز ديب } & \multicolumn{2}{|c|}{ آزمون شإِيرو فرانسيا } & \multirow{2}{*}{ سازه حسابدارى ذهنى } \\
\hline معنادارى & آماره D & معنادارى & 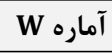 & \\
\hline$\cdot / \cdots v$ & .1 .94 & $\cdot / \cdot r 4$ & .1994 & فكر كردن در مورد ماليات \\
\hline.$/ \cdot T t$ & $\cdot 1 \cdot \Delta \Lambda$ & $\cdot 1 \cdot \cdot 19$ & .1971 & يسانداز براى ماليات \\
\hline$\cdot / \cdots v$ & .1 .94 & $\cdot / \cdot \Delta F$ & .1991 & ماليات بر درآمد \\
\hline$\cdot 1 \cdots 1$ & $\cdot 1 \cdot V r$ & .1 .999 & .1981 & ماليات بر ارزش افزوده \\
\hline
\end{tabular}

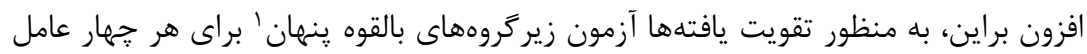

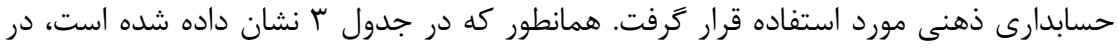

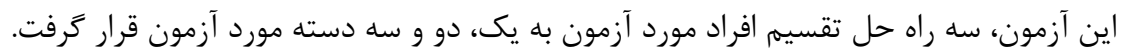
جدول با: نتايج حاصل از آزمون زيركروههاى بالقوه ينهان

\begin{tabular}{|c|c|c|c|c|c|c|c|}
\hline \multicolumn{4}{|c|}{ حسابدارى ذهنى } & & & & \\
\hline |رارش افزوده & ماليات بر & ماليات مانداز براى & فكر كردن در ماليات & & & & \\
\hline ميانگين & ميانخين & ميانگَين & ميانگَين & تعداد & دسته & معيار اطلاعات بيزى & راه حل \\
\hline$\mu / \cdot 1$ & $r / \cdot F$ & T/AF & $r / 4$ & $1 \Lambda F$ & دسته 1 & ITFT/MFE & بك دسته \\
\hline$r / I T$ & $r / \cdot q$ & $r / V q$ & r/AT & 1.9 & دسته 1 & $|r| r / \Delta r q$ & دو دسته \\
\hline$r / \Delta \Lambda$ & $r / 9 \varphi$ & $r / 91$ & $r / \mathcal{L}$. & $\vee \wedge$ & دسته r & & \\
\hline$r / \cdot r$ & $r / 9 V$ & T/VG & $r|f|$ & pq & دسته 1 & ما & سه دسته \\
\hline$r / \cdot \Delta$ & r/l & $r|\Lambda|$ & r/r & $\Delta V$ & دسته r & & \\
\hline$r / 91$ & $r / 9 F$ & $r / 9 V$ & $r / F F$ & $\vee \wedge$ & دسته r & & \\
\hline
\end{tabular}

${ }^{1}$ Latent Profile Analyses 


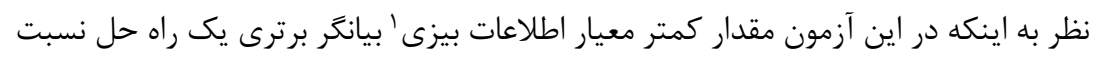

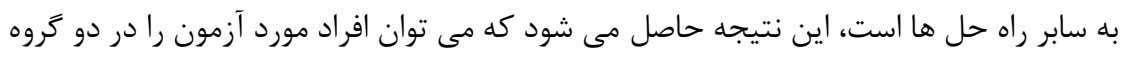

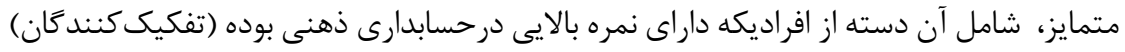

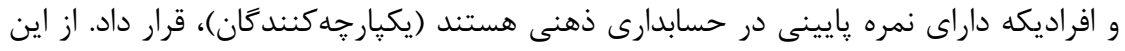

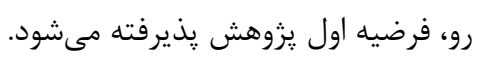

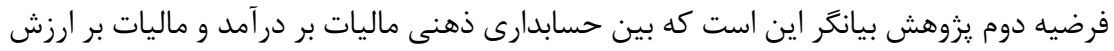

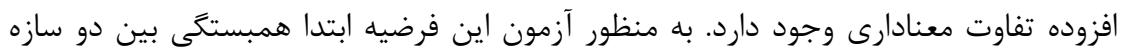

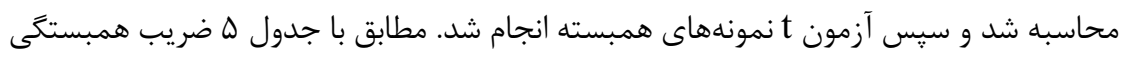

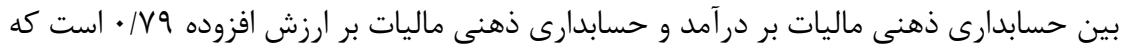

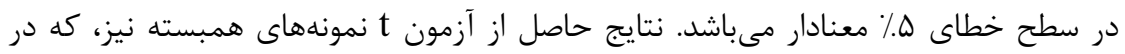

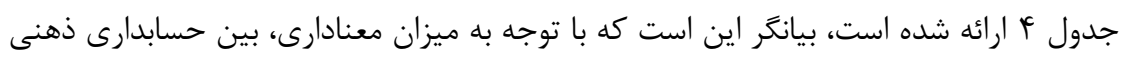

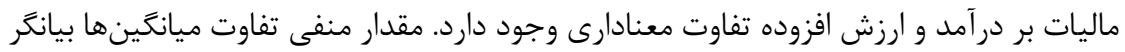

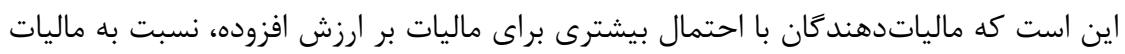

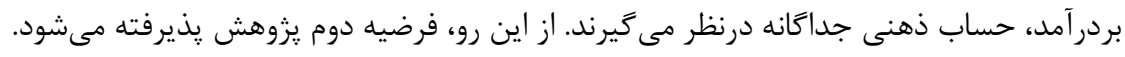

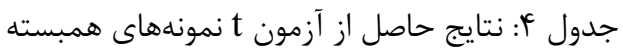

\begin{tabular}{|c|c|c|c|}
\hline معنادارى & تفاوت ميانكَينها & 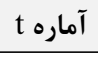 & سازهها \\
\hline$<\cdot \mid \cdot \cdot 1$ & $-1 \% / 9$. & $-1 \cdot / \mu^{4}$ & حسابدارى ذهنى ماليات بر درآمد و ماليات بر ارزش افزوده \\
\hline
\end{tabular}

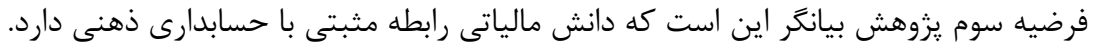

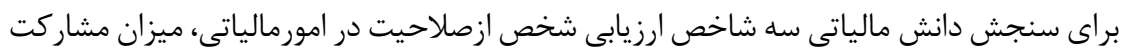

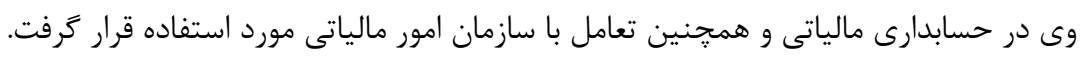

\begin{tabular}{|c|c|c|c|c|c|}
\hline ماليات بر ارزش & ماليات بر & ماليات & فور كردن در ماليات & |صلاحيت در & سازه \\
\hline & & & & 1 & صلاحيت در امور مالياتى \\
\hline & & & 1 & $\cdot / V \Lambda^{*}$ & فكر كردن در مورد ماليات \\
\hline & & 1 & $\cdot / \Lambda \Delta^{*}$ & . $/ \Lambda Y^{*}$ & يس پسانداز براى ماليات \\
\hline & 1 & $\cdot / 9 \cdot *$ & $\cdot / \Lambda \Delta^{*}$ & $\cdot / V^{* *}$ & ماليات بر درآمد \\
\hline 1 & $\cdot / V 9^{*}$ & $\cdot \mid \Lambda \mu^{*}$ & $\cdot / V \Lambda^{*}$ & $\cdot / 4 Q^{*}$ & ماليات بر ارزش افزوده \\
\hline
\end{tabular}

${ }^{1}$ Bayesian Information Criterion 
به منظور آزمون فرضيه سوم ضرايب همبستخى بين جهار عامل حسابدارى ذهنى و سه

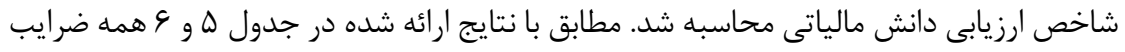

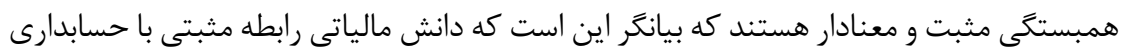

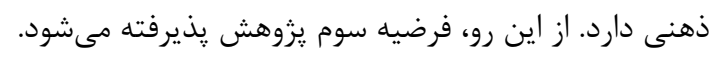

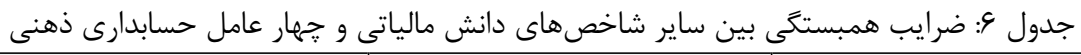

\begin{tabular}{|c|c|c|c|c|}
\hline \multicolumn{2}{|c|}{ تعامل با مقامات مالياتى } & \multicolumn{2}{|c|}{ مشاركت در حسابدارى مالياتى } & \multirow[b]{2}{*}{ 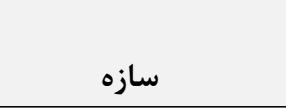 } \\
\hline معنادارى & ضريب همبستگى & 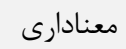 & ضريب همبستكى & \\
\hline$\cdot 1 \cdot v V$ &.$/ 4 T$ & $<\cdot 1 \cdot \cdot 1$ & . IAV & فكر كردن در مورد ماليات \\
\hline$<\cdot / \cdot \cdot 1$ & .109 & $<\cdot 1 \cdot \cdot 1$ & $\cdot / \mathrm{VA}$ & يس بـانداز براى ماليات \\
\hline$\cdot 1 \cdots 1$ &.$/ 44$ & $<\cdot / \cdot \cdot 1$ & .119 & ماليات بر درآمد \\
\hline$<\cdot / \cdot \cdot 1$ & $\cdot / \mathrm{VI}$ & $<\cdot / \cdot \cdots$ & .199 & ماليات بر ارزش افزوده \\
\hline
\end{tabular}

فرضيه جهارم يزوهش بيانكر اين است كه حسابدارى ذهنى رابطه مثبتى با تمكين مالياتى إنى

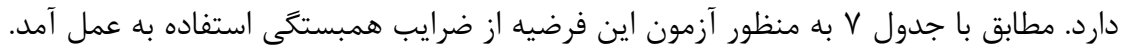

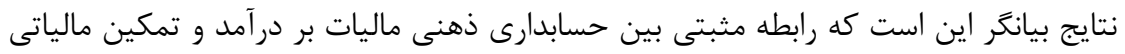

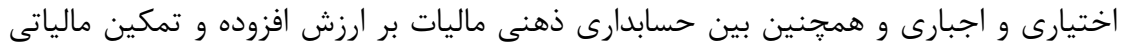

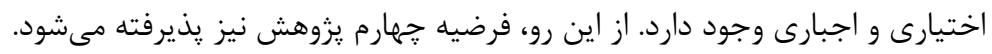

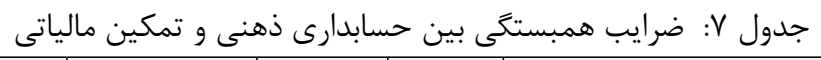

\begin{tabular}{|c|c|c|c|c|}
\hline حسابدارى ذهنى افز ارزش & 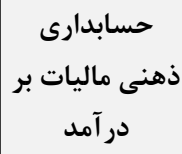 & اجمالياتى & مالياتى & سازه \\
\hline & & & 1 & تمكين مالياتى اختيارى \\
\hline & & 1 & $\cdot / \Lambda \Delta^{*}$ & تمكين مالياتى اجبارى \\
\hline & 1 & $.199^{*}$ & $.19 \Lambda^{*}$ & حسابدارى ذهنى ماليات بر درآمد \\
\hline 1 & $\cdot / \mathrm{V} 9 \%$ & $\cdot / V \Lambda^{*}$ & $\cdot / A V^{*}$ & حسابدارى ذهنى ماليات بر ارزش افزوده \\
\hline
\end{tabular}

\section{9- ونتيجه كيرى و بحث}

هدف يزوهش حاضر بررسى نقش حسابدارى ذهنى در رفتار مالياتى خويش فرمايان با باريا

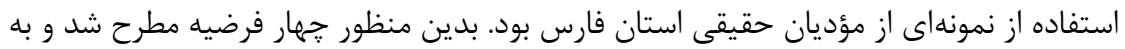

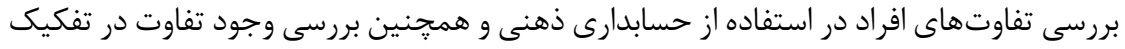

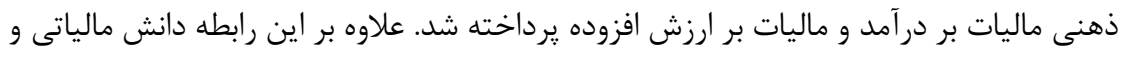


استفاده از حسابدارى ذهنى و همجنين رابطه حسابدارى ذهنى و تمكين مالياتى مورد بررسى إسى

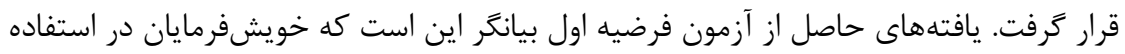

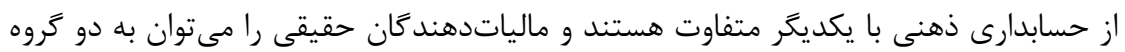
تفكيك كنند

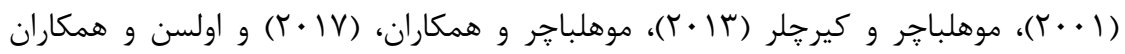

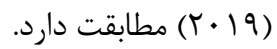

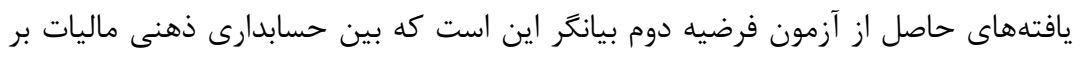

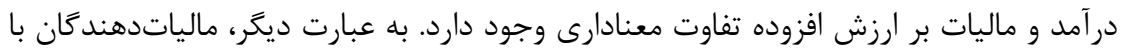

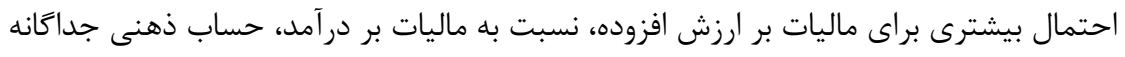

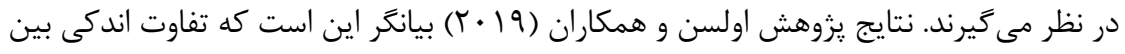

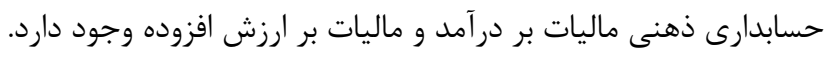

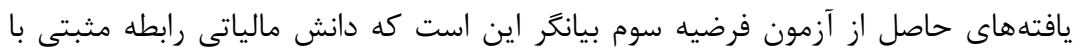

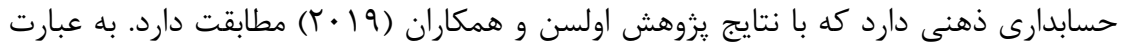

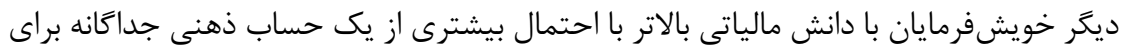

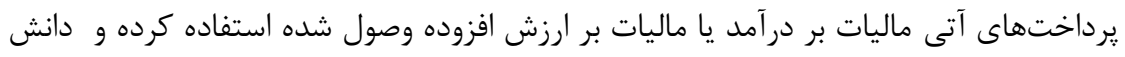

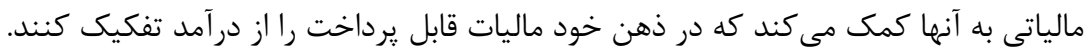

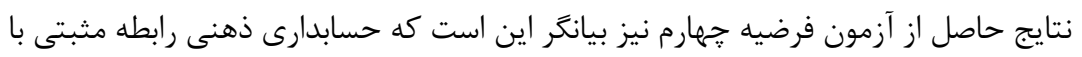

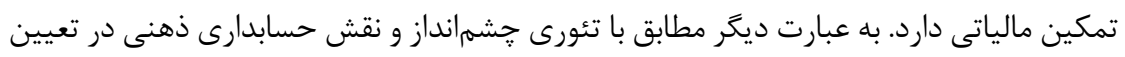

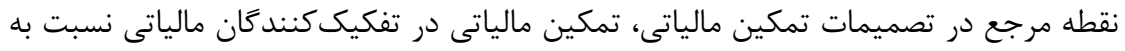

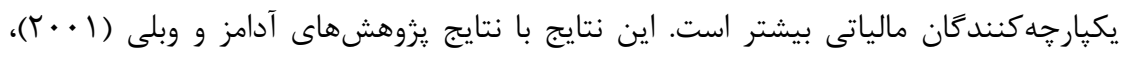

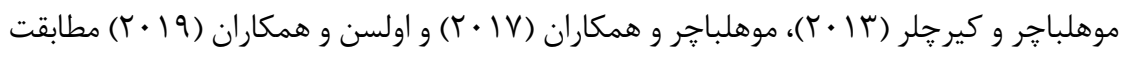

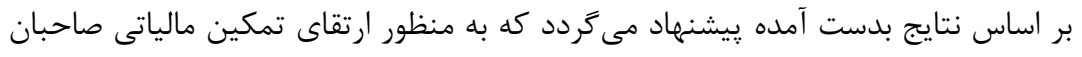

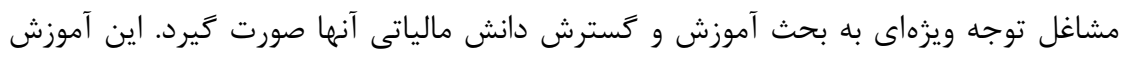

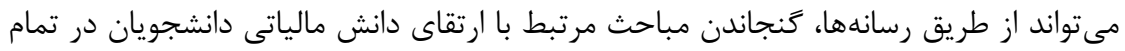

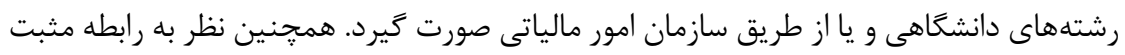

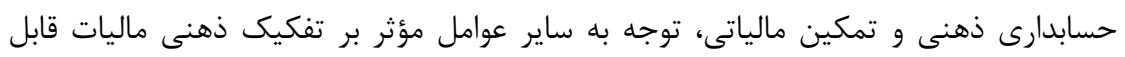

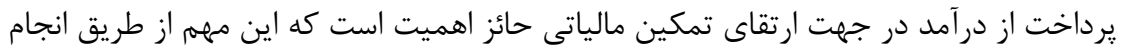

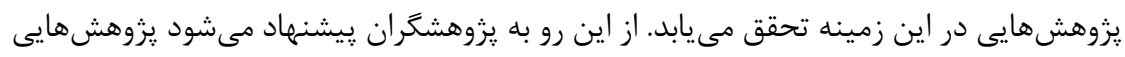

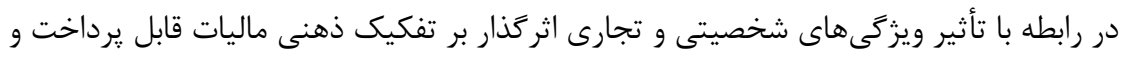



دكتر ابراهيمى و نجفى، نقش حسابدارى ذهنى در رفتار مالياتى خويش فرمايان ... درآمد انجام دهند. همجنين يِشنههاد مىشود كه اين يزوهش در ساير استانها نيز انجام شود تا

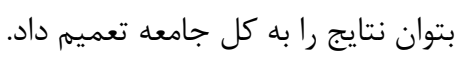

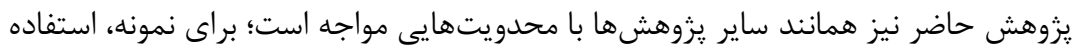

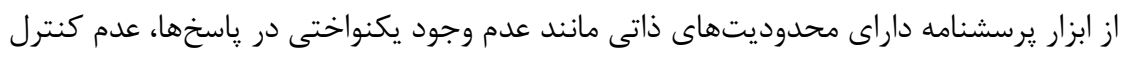

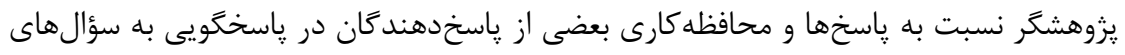

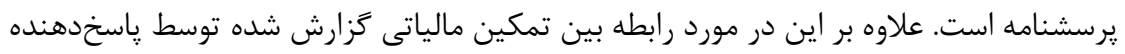

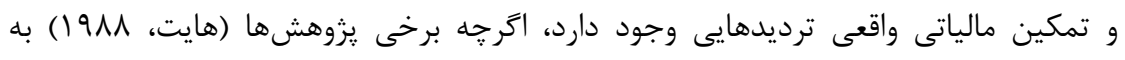

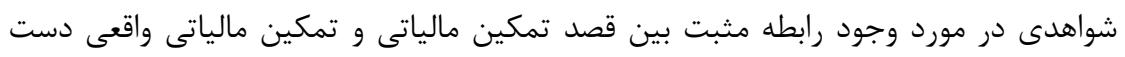
يافتهاند.

\section{V- تقدير و تشكر و ملاحظه هاى اخلاقى}

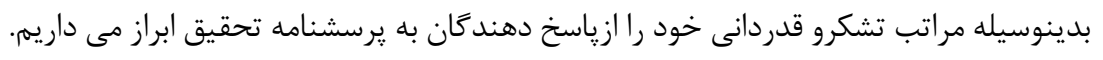

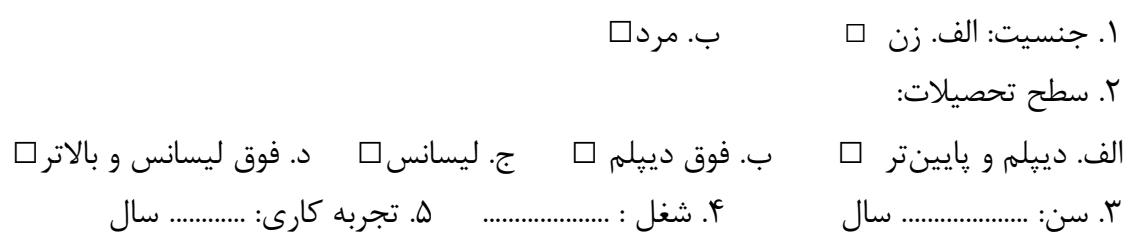

سؤالهاى تخصصى

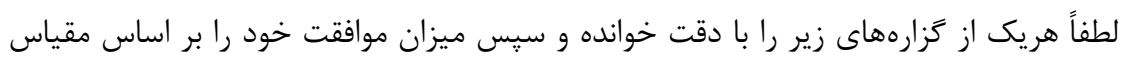
زير مشخص فرماييد. 1. من فكر مى كنم كه در مورد ماليات سررشته دارم.

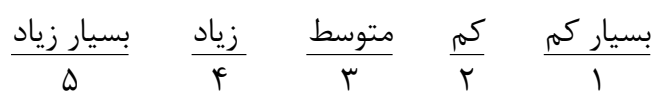
r. من فكر مى كنم كه توانايى ير كردن اظهارنامه مالياتى خود را دارم.

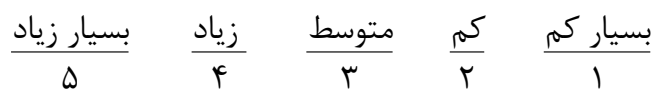
r. هنكامى كه يك دوست از من در مورد يك موضوع مالياتى سؤال مى كند، فكر مى كنم كه

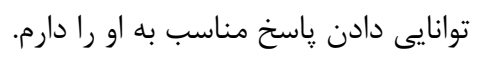

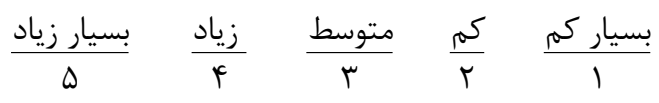




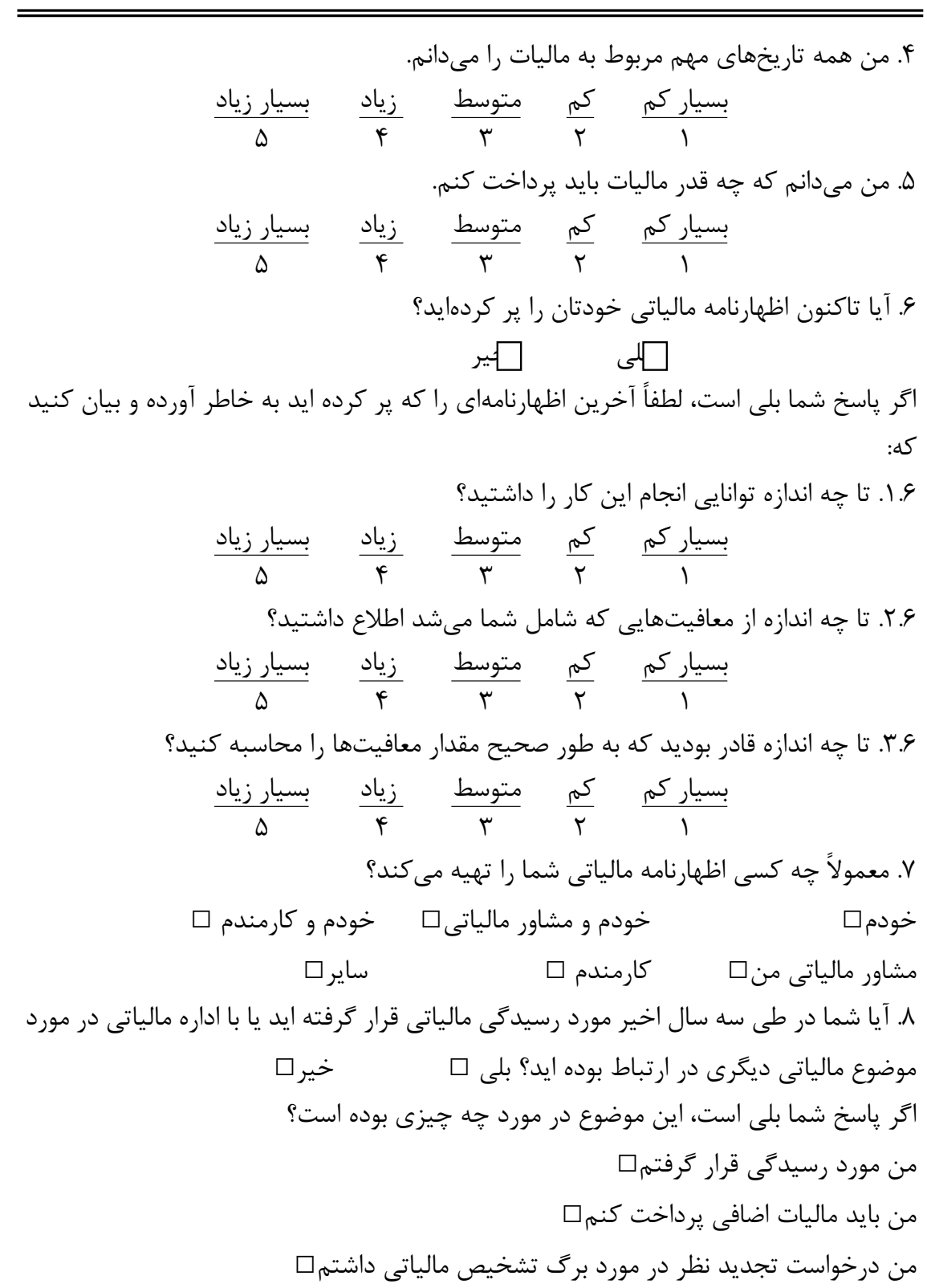




$$
\begin{aligned}
& \text { لطفاً هريك از گزارههاى زير را با دقت خوانده و سيس ميزان موافقت خود را بر اساس مقياس } \\
& \text { زير مشخص فرماييد. } \\
& \text { ا. وقتى كه فروش من افزايش مىيابد، مىدانم كه اين افزايش فروش باعث افزايش ماليات }
\end{aligned}
$$

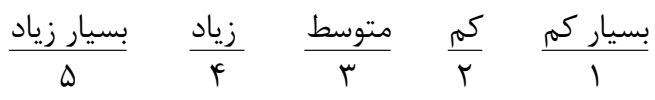

$$
\begin{aligned}
& \text { r. هنغامى كه من يولى را بدست مى آورم خود به خود به ماليات آن فكر مى كنهم. }
\end{aligned}
$$

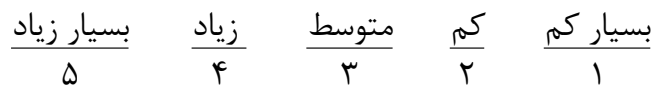

$$
\begin{aligned}
& \text { مىشود. }
\end{aligned}
$$

r. من فقط زمانى به ماليات فكر مى كنم كه موعد تنظيم و تحويل اظهارنامه مالياتى باشد.

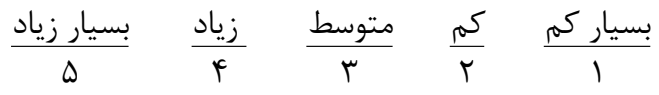

$$
\begin{aligned}
& \text { f. من در ذهن خودم ماليات را از فروش صورت گرفته تفكيك مى كنه. }
\end{aligned}
$$

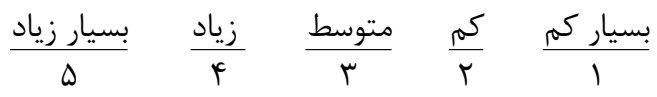

ه. من زمانى كه قيمت كالا يا خدمات خود را تعيين مى كنم به سود بعد از ماليات آن نيز فكر

$$
\text { مى كنم. }
$$

9. هنغامى كه كسب و كار من در يك سال به صورت استثنايى خوب است، من در مورد مبلغ

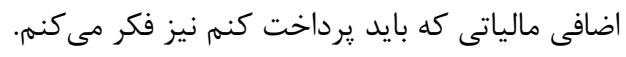

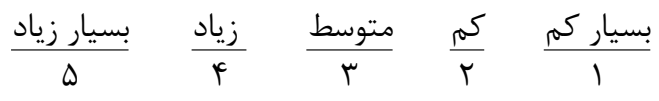

V. در زندگى روزمره خود همه فروش خود را به عنوان سود تلقى مى كنم.

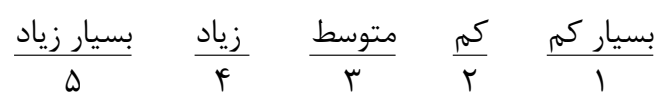

$$
\text { ^. من براى يرداخت ماليات درآينده يول كنار مى كذارم. }
$$

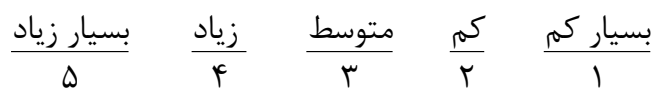

9. من يولى را كه براى يرداخت ماليات در آينده كنار كذاشتهام، در موارد ديكر خرج نمى كنم.

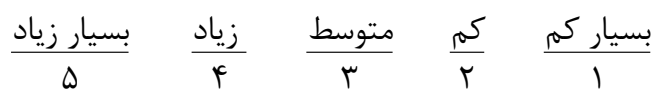


• 1. من دقيقاً مىدانم كه جه مقدار يول بايد براى ڤبرداختهاى آينده ماليات كنار بكذارم.

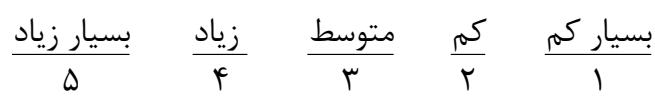

11 ا. من يك حساب بانكى جداگانه به منظور پِ انداز يول براى يرداختهاى ماليات آينده دارم.

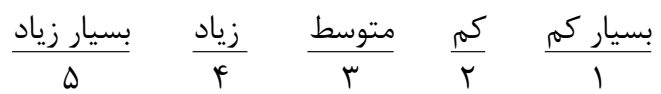

r ا. يول يرداخت شده به اداره امور مالياتي، يول من نيست؛ بلكه مشتريان من آن را يرداخت

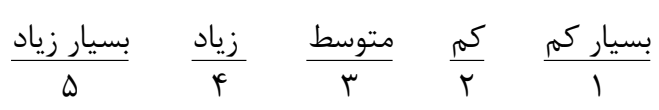

rا. من گاهى اوقات يولى را كه براى برداختهاى ماليات در آينده كنار كذاشتهام در موارد

$$
\text { ديغرى نيز خرج مى كنم. }
$$

اكنون در مورد ماليات بر درآمد فكر كنيد و سيس ميزان موافقت خود را بر اساس مقياس زير مشخص فرماييد.

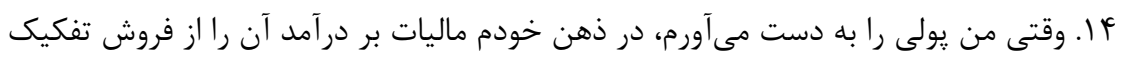

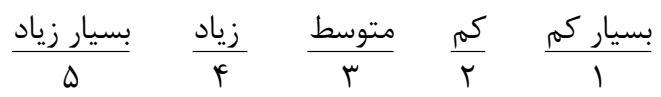

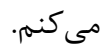

ها. من به منظور يرداخت ماليات بر درآمد اضافى احتمالى مبلنى يول كنار مى كذارم.

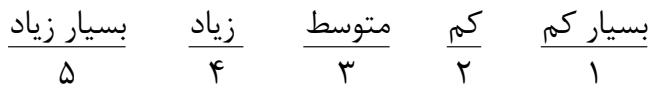

19. هنكامى كه من درآمدى بيشتر از درآمد سال قبل كسب مى كنم، يولى را براى يرداخت

$$
\text { ماليات بر در آمد اضافى كنار مى كذارم. }
$$

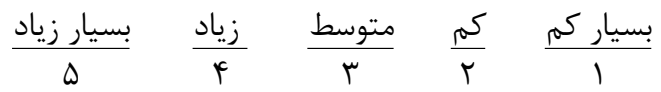

Vا. ماليات بر درآمد صرفاً يولى است كه توسط من وصول و به اداره امور مالياتى برداخت مىشود؛ در حقيقت مشتريان من ماليات را برداخت مى كنند.

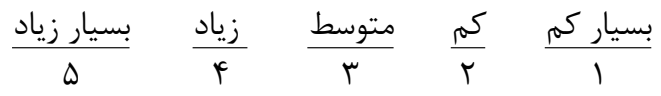


พq) دكتر ابراهيمى و نجفى، نقش حسابدارى ذهنى در رفتار مالياتى خويش فرمايان ...

11. هنگامى كه من ماليات بر درآمد را به اداره امور مالياتى يرداخت مى كنم آن را به منزله يك

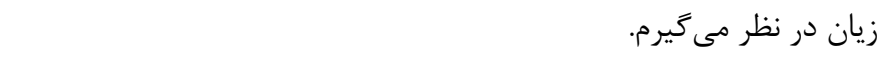

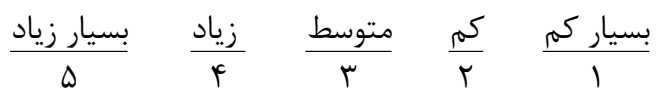

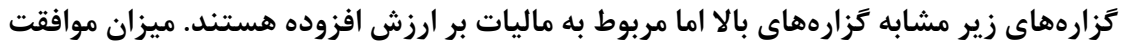
خود را بر اساس مقياس زير مشخص فرماير مقابيد

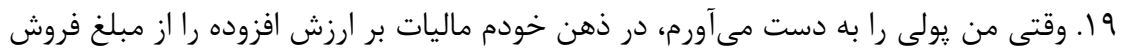

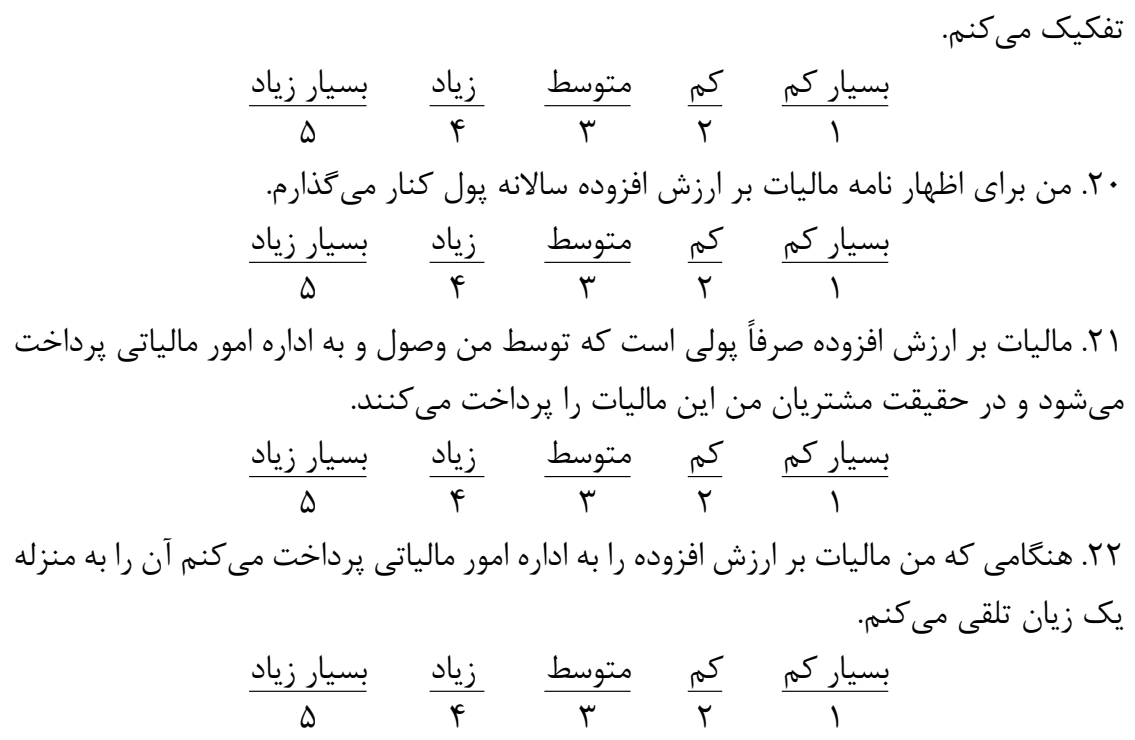
لطفاً هريك از تزارههاى زير را با دقت خوانده و سيس ميزان موافقت خود را بر اساس مقياس زير مشخص فرماييد. هنكامى كه من طبق قانون، ماليات بر درآمد را يرداخت مى كنم اين كار را به اين دليل انجام مى בهم كa: ا. براى من واضح است كه اين كار بايد انجام شود.

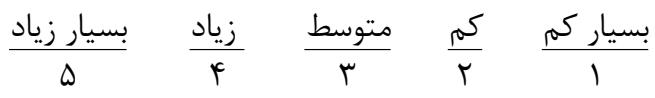

$$
\begin{aligned}
& \text { r. من اين كار را وظيفه خود به عنوان يك شهروند مى انهم. }
\end{aligned}
$$

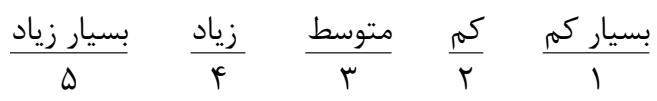




$$
\begin{aligned}
& \text { r. اداره امور مالياتى اغلب رسيدگى هايى را انجام مى دهد. }
\end{aligned}
$$

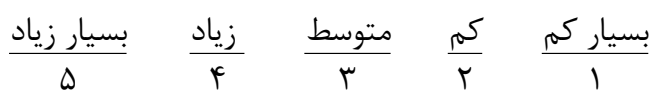

$$
\begin{aligned}
& \text { f أ. جرايم فرار مالياتى بسيار شديد هستند. }
\end{aligned}
$$

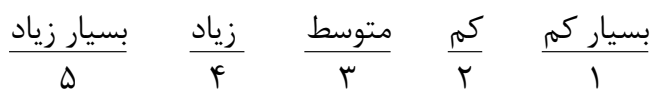

$$
\begin{aligned}
& \text { هنكامى كه من طبق قانون، ماليات بر ارزش افزوده را برداخت مى كنم اين كار را به اين دليل }
\end{aligned}
$$

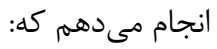

$$
\begin{aligned}
& \text { ا. براى من واضح است كه اين كار بايد انجام شود. }
\end{aligned}
$$

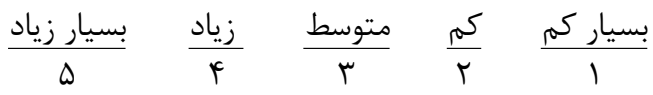

$$
\begin{aligned}
& \text { r. من اين كار را وظيفه خود به عنوان يك شهروند مى دانم. }
\end{aligned}
$$

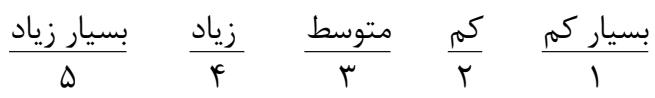

$$
\begin{aligned}
& \text { r. اداره امور مالياتى اغلب رسيدگى هايى را انجام مى دهد. }
\end{aligned}
$$

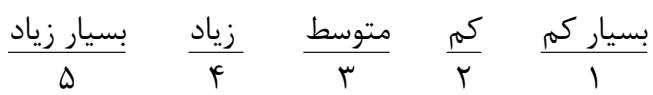

$$
\begin{aligned}
& \text { F أ. جرايم فرار مالياتى بسيار شديد هستند. }
\end{aligned}
$$

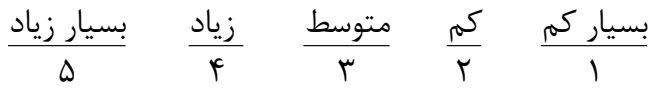

$$
\begin{aligned}
& \text { فهرست منابع }
\end{aligned}
$$

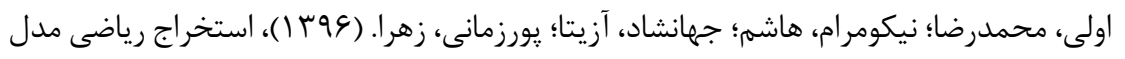

$$
\begin{aligned}
& \text { قيمت كذارى دارايىهاى سرمايهاى در خار جوب حسابدارى ذهنى، دانش مالى الى تحليل }
\end{aligned}
$$

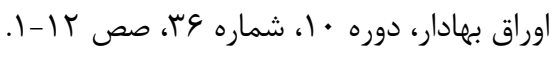

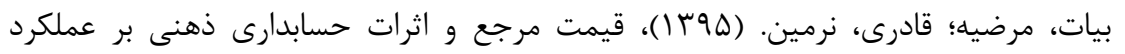

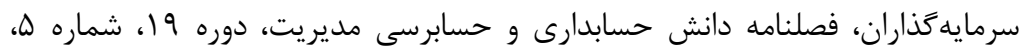

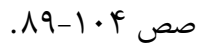

$$
\begin{aligned}
& \text { بهشتى، يعقوب؛ رويايى، رمضانعلى. (צ9 (1). بررسى رابطه بين فلسفه اخلاق فردى و نكَرش فرار }
\end{aligned}
$$

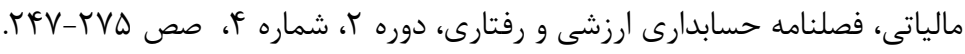



دكتر ابراهيمى و نجفى، نقش حسابدارى ذهنى در رفتار مالياتى خويش فرمايان ...

$$
\begin{aligned}
& \text { ״ارسايى، منا؛ ملانظرى، مهناز. (191 (1)، نقش حسابدارى ذهنى در تصميمات بودجهبندى }
\end{aligned}
$$

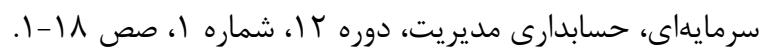

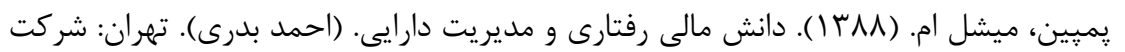

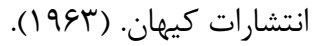

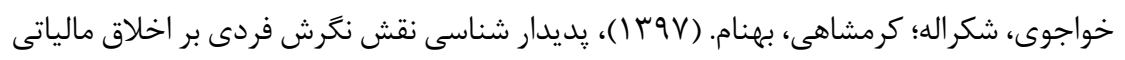

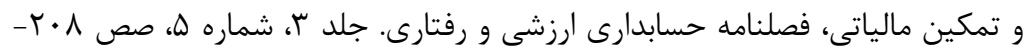

$$
\begin{aligned}
& . I \wedge \mathrm{V}
\end{aligned}
$$

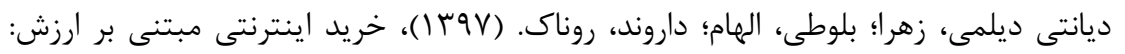

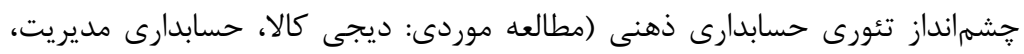

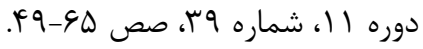

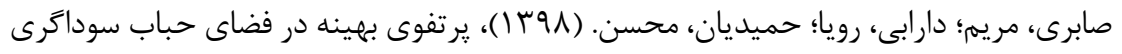

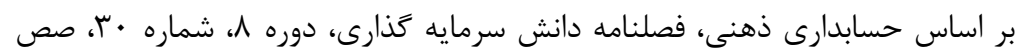

$$
\begin{aligned}
& .191-r \mid \cdot \\
& \text { عرب مازار، على اكبر؛ گل محمدى، مريم؛ باقرى، بهروز. ( • و (1)، سطح تمكين مالياتى، مههمترين } \\
& \text { شاخص دستيابى به يك نظام مالياتى مطلوب و كار آمد، يزوهشنامه ماليات، دوره } 19 \text { 19، }
\end{aligned}
$$

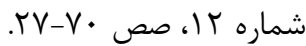

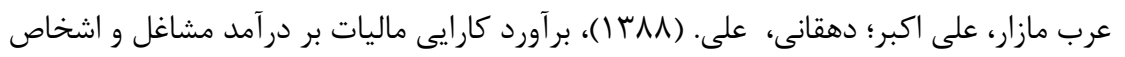

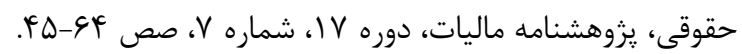

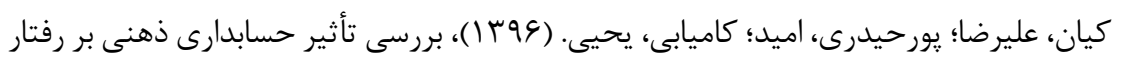

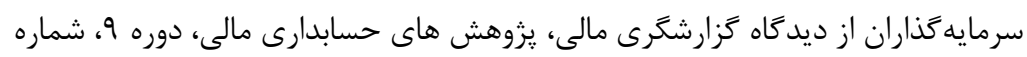

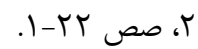

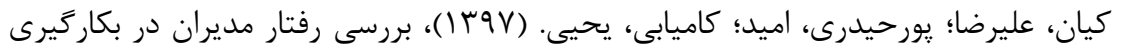

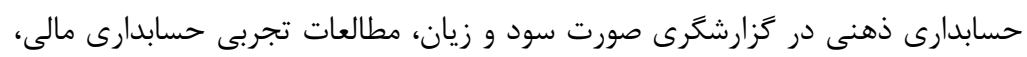

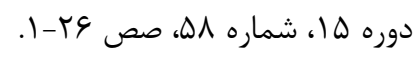

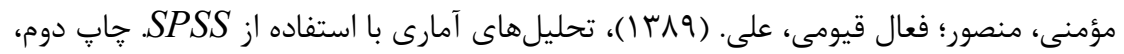

$$
\begin{aligned}
& \text { تهران: انتشارات كتاب نو. }
\end{aligned}
$$

Adams, C., and P. Webley. 2001. Small business owners' attitudes on VAT compliance in the UK. Journal of Economic Psychology 22:195-216.

Ashby, J. S., and P. Webley. 2008a. But everyone else is doing it': a closer look at the occupational taxpaying culture of one business sector. Journal of Community \& Applied Social Psychology 18:194-210. 
Ashby, J. S., and P. Webley. 2008b. The trick is to stop thinking of it as 'your' money: mental accounting and taxpaying. Paper presented at the IAREP/SABE World Meeting 2008: Economics and Psychology: Methods and Synergies, Rome, Italy

Chambers, V., and M. Spencer. 2008. Does changing the timing of a yearly individual tax refund change the amount spent vs. saved?. Journal of Economic Psychology 29:856-62.

Hite, P. A. 1988. An examination of the impact of subject selection on hypothetical and self-reported taxpayer noncompliance. Journal of Economic Psychology 9: 445-466.

Jackson, S. B., Shoemaker, P. A., Barrick, J. A., and F. G. Burton. 2005. Taxpayers' prepayment positions and tax return preparation fees. Contemporary Accounting Research 22(2): 409-447.

Muehlbacher, S., and E. Kirchler. 2013. Mental accounting of selfemployed taxpayers: on the mental segregation of the net income and the tax due. FinanzArchiv: Public Finance Analysis 69:412-38.

Muehlbacher, S., Hartl, B., and E. Kirchler. 2017. Mental accounting and tax compliance: experimental evidence for the effect of mental segregation of tax due and revenue on compliance. Public Finance Review 45(1): 118-139.

Olsen, J., Kasper, M., Kogler, C., Muehlbacher, S., and E. Kirchler 2019. Mental accounting of income tax and value added tax among selfemployed business owners. Journal of Economic Psychology 70: 125139.

Thaler, R. H. 1985. Mental accounting and consumer choice. Marketing Science 4: 199-214.

Thaler, R. H. 1999. Mental accounting matters. Journal of Behavioral Decision Making 12:183-206.

Tversky, A., and D. Kahneman, 1989. Rational choice and the framing of decisions. In Multiple criteria decision making and risk analysis using microcomputers 81-126. Springer, Berlin, Heidelberg. 